DIW BERLIN

Discussion

Papers
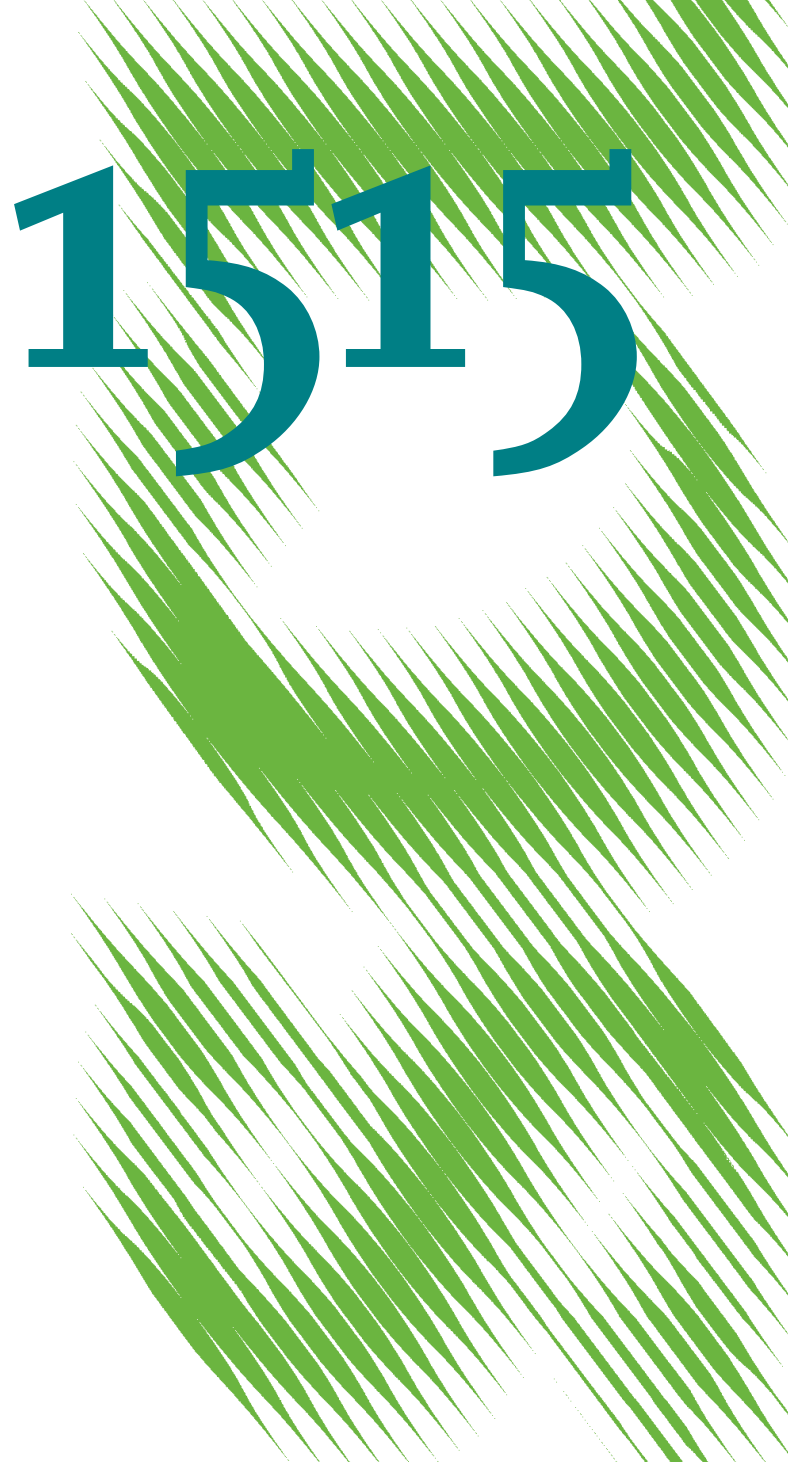

Does Index Insurance Help

Households Recover from Disaster?

Evidence from IBLI Mongolia 
Opinions expressed in this paper are those of the author(s) and do not necessarily reflect views of the institute.

IMPRESSUM

(C) DIW Berlin, 2015

DIW Berlin

German Institute for Economic Research

Mohrenstr. 58

10117 Berlin

Tel. +49 (30) $89789-0$

Fax +49 (30) $89789-200$

http://www.diw.de

ISSN electronic edition 1619-4535

Papers can be downloaded free of charge from the DIW Berlin website:

http://www.diw.de/discussionpapers

Discussion Papers of DIW Berlin are indexed in RePEc and SSRN:

http://ideas.repec.org/s/diw/diwwpp.html

http://www.ssrn.com/link/DIW-Berlin-German-Inst-Econ-Res.html 


\title{
Does index insurance help households recover from disaster? Evidence from IBLI Mongolia*
}

\author{
Veronika Bertram-Huemmer $^{\dagger} \quad$ Kati Kraehnert $^{\ddagger}$
}

October 30, 2015

\begin{abstract}
This paper investigates the impact of indemnity payments from index insurance on the asset recovery of households after a catastrophic weather disaster occurs. Our focus is on the Index-Based Livestock Insurance (IBLI) in Mongolia. We analyze the effect of IBLI indemnity payments after a once-in-50-year winter disaster struck Mongolia over 2009/10. The database for our analysis is three waves of a household panel survey implemented in western Mongolia. We employ the bias-corrected matching estimator to account for selection into purchasing IBLI. Results indicate that pastoralist households purchasing IBLI before the shock recover faster from shock-induced asset losses than comparable non-insured households. We find a significant, positive and economically large effect of IBLI indemnity payments on herd size one and two years after the shock. In the medium term - three and four years after the shock - the effect slowly vanishes. Results are robust to defining post-shock livestock recovery in different ways, varying the number of matches per observation, the choice of covariates, and the use of alternative propensity score estimators. An analysis of shock coping strategies as well as complementary qualitative interviews conducted in the field suggest that indemnity payments help herders to avoid selling and slaughtering animals and smooth their productive asset base. Also, IBLI appears to have relieved households from credit constraints. Our study is among the first to provide evidence on the beneficial effects of index insurance after a weather shock in a developing economy.
\end{abstract}

Keywords: index insurance, livestock, weather shocks, Mongolia.

JEL Classification Numbers: O12, O13, Q14.

\footnotetext{
${ }^{\dagger}$ German Institute for Economic Research, Mohrenstrasse 58, 10117 Berlin, Germany; Email: vhuemmer@diw.de

${ }^{\ddagger}$ German Institute for Economic Research, Mohrenstrasse 58, 10117 Berlin, Germany; Email: kkraehnert@diw.de *We are grateful to Timothée Demont, Jan Eberle, Nathan Fiala, Valeria Groppo, Kriztina Kis-Katos, Andreas Landmann, Adam Lederer, Friederike Lenel, Wei Liu, Mushfiq Mobarak, Dan Osgood, Jerry Skees, Susan Steiner and Ulziibold Yadamsuren for helpful comments. The paper benefited from presentations at seminars and conferences in Boston (AEA), New York (IRI at Columbia University), Laxenburg/Vienna (IIASA), Munich (MicroInsurance Network), Hannover (EUDN), and Berlin (DIW, EALE and Geneva Association). Uuriintuya Batsaikhan, Undraa Damdinsuren and Bayarkhuu Chinzorigt provided excellent research assistance. We are very grateful to the National Statistical Office of Mongolia for the fruitful cooperation in collecting household survey data. The research was generously funded by the German Federal Ministry of Education and Research, funding line "Economics of Climate Change", research grant 01LA1126A. Veronika Bertram-Huemmer also thanks DIW Berlin and IIASA for generous funding. The responsibility for the content of this paper lies solely with the authors.
} 


\section{Introduction}

Index-based insurance was first introduced in the early 2000s in order to help agricultural households in developing countries cope with weather risks. Index insurance transfers covariate weather risks outside the local community and provides liquidity in the aftermath of a shock (Skees and Barnett 2006; Barnett and Mahul 2007; Barnett et al. 2008 Carter 2009). In the event of a weather disaster, insurance indemnity payments are expected to help households to recover from the damage caused by the weather shock. It is further hoped that index insurance enables households in general to make investment decisions involving higher risk and higher profit opportunities. Despite the great enthusiasm with which index insurance is discussed in the policy community, there is little evidence of whether index insurance indeed provides its expected benefits (Miranda and Farrin 2012 World Bank Group 2013 Carter et al. 2014 Greatrex et al. 2015).

This paper investigates the impact of indemnity payments from index insurance on the asset recovery of households after a catastrophic weather disaster occurs. Our focus is on the Index-Based Livestock Insurance (IBLI) in Mongolia. IBLI indemnity payments were triggered following the 2009/10 winter, when Mongolia was struck by a severe winter disaster (called $d z u d$ in Mongolian). Extremely cold temperatures, excessive snowfall, and an overall long duration of the winter caused the death of more than 10 million livestock, more than 23 percent of the national stock. In rural Mongolia, where the majority of the population depends upon herding activities for their livelihood, the 2009/10 dzud caused wide-spread poverty among herders (IFRC and MRCS 2010, Sternberg 2010). Our analysis builds on three waves of a household panel survey that we implemented in three western Mongolia provinces. We find a significant, positive and economically large effect of IBLI indemnity payments on households' post-disaster recovery in livestock. Thus, our study is among the first to document empirically a case in which index insurance works.

The main challenge when evaluating the impact of a commercial product such as IBLI is that uptake is voluntary. Households voluntarily decide for or against purchasing IBLI, which is nationally advertised in the media and sold locally by insurance agents. The IBLI program was implemented without randomized assignment rules at the household level. Thus, our empirical strategy needs to account for selection into treatment with quasi-experimental methods. We employ the bias-corrected matching estimator to control for self-selection into purchasing IBLI before the disaster winter and receiving IBLI indemnity payments in 2010. Our analysis rests on the assumption that selection into treatment is independent of the outcome after controlling for observed covariates, with no unobservable factors remaining. Two factors help us to reduce the potential bias due to unobserved characteristics. First, we exploit the phasing-in of the IBLI program. When the dzud disaster of 2009/10 occurred, IBLI was still in its pilot stage and only available in one of the three survey provinces. We match treated households living in the province where IBLI was available in 2009 with control households living in the two other provinces where IBLI was not yet offered. This way, we increase the likelihood that treated and control households share similarities in unobserved characteristics. Moreover, the household survey questionnaire records detailed retrospective information on households' pre-shock herd size, livestock losses due to the winter disaster, as well as an unusually large number of household characteristics that we use to account for selection into treatment. 
Our contribution to the small but growing empirical literature on the impact of index insurance on households is twofold. First, most existing studies focus on the effects of insurance uptake on households' investment behavior (e.g., Giné and Yang 2009, Mobarak and Rosenzweig 2012, 2013, 2014 Karlan et al. 2014). This focus is due to the fact that index insurance was only first introduced in the early 2000s. In most empirical settings, a major weather shock that would have triggered indemnity payments has not (yet) occurred. A common conclusion in these empirical studies is that index insurance enables agricultural households to make larger and more profitable, but also riskier, investments. Yet, to the best of our knowledge, only one study by Janzen and Carter (2013) investigates the impact of indemnity payments from index insurance triggered by a drought. Janzen and Carter show that indemnity payments influence the shock coping strategies that households intend to use. We complement the study by Janzen and Carter by documenting that IBLI indemnity payments have an impact on observed asset dynamics of households after a weather disaster. Moreover, we use data on households' livestock holdings one, two, three and four years after the disaster and thus provide evidence on the persistence of the effect over time.

Second, our study is the first quantitative assessment of IBLI Mongolia, an index insurance program that is followed with great attention by policy stakeholders and insurance companies. Shortly after its implementation in pilot areas in 2006, IBLI had already created a sufficiently high demand (above 20 percent in some provinces) for it to be scaled up to the national level in 2012. It is the only index insurance to date that has been transferred into an independent commercial insurance scheme. In contrast, most index insurance schemes that are implemented in developing countries are still in the pilot stage (Carter et al. 2014). So far, most of those schemes are either implemented on a small scale or heavily subsidized and thus not commercially viable. Almost all index insurances struggle with low uptake (Binswanger-Mkhize 2012 Miranda and Farrin 2012; Carter et al. 2014).

Results show a significant and positive effect of IBLI indemnity payments on households' recovery in livestock holdings in the first and second year following the 2009/10 winter disaster. Two years after the disaster, insured households own between 22 percent and 27 percent more livestock, which is the key indicator for welfare in rural Mongolia. The positive effect of indemnity payments is still visible, but less pronounced, three and four years after the disaster. These results hold when defining the outcome variables in different ways (herd size and livestock growth rates), when varying the numbers of matches per observation, when using different sets of covariates, when accounting for herd composition, and when using alternative propensity score estimators. Finding a consistently significant and economically large effect of IBLI indemnity payments took us by surprise: Given that incomplete insurance is prevalent among IBLI customers (with households only purchasing insurance for a minor share of their livestock holdings) and given that our sample comprises a relatively small number of insured households, we did not expect to find strong results when beginning our analysis.

We further provide indicative evidence on the channels through which IBLI helped households to recover. This evidence is derived from analyzing households' shock coping strategies (again using the bias-corrected matching estimator) as well as complementary qualitative fieldwork in Mongolia. On the one hand, indemnity payments helped herders avoid selling and slaughtering animals, thus smoothing their productive asset base. On the other hand, IBLI appears to have relieved households from credit constraints, which may have been used to purchase new livestock after the disaster. 
The remainder of this paper is structured as follows: Section 2 provides a brief overview of existing empirical studies on index insurance. Section 3 provides contextual information on herding and weather risk in Mongolia and presents the design of IBLI. The household survey data are described in section 4 , followed by an outline of the identification strategy in section 5. Section 6 presents estimation results and robustness tests as well as a discussion on the potential channels. Section 7 concludes.

\section{Review of existing studies on index insurance}

Given that index insurance is a relatively new product, the empirical literature on the impact of index insurance on households is still small. Existing research mostly focuses on the ex ante effects of insurance uptake on households' risk management behavior. A common finding is that index insurance enables agricultural households to make riskier investments that generate higher returns. For instance, Karlan et al. (2014) find that farmers in northern Ghana who purchased index insurance cultivate more land, increase their efforts in preparing the land, and spend more on fertilizers. In a study on index insurance offered to cotton cooperatives in Mali, Elabed and Carter (2014) show that insured households cultivate a larger area of land with cotton and invest more in seeds. Hill and Viczeisza (2012) carry out an experimental game with Ethiopian farmers who are offered a stylized index insurance. Results indicate that index insurance increases the likelihood that farmers purchase fertilizer. In a series of papers, Mobarak and Rosenzweig $2012,2013,2014)$ show that even when informal risk-sharing networks are present, index insurance entices farmers in India to take greater risks. Insured farmers are more likely to plant a portfolio of rice varieties that are less drought-resistant, but generate higher yields. In a study of rural households in Andhra Pradesh, Cole et al. (2013) find that insured farmers allocate more agricultural inputs to the production of crops that generate higher expected returns, but are more sensitive to deficient rainfall. All of the cited studies are based on randomized experiments to identify the effects of index insurance. Moreover, all of the cited studies either focus on small index insurance schemes that are heavily subsidized or use stylized index insurance in the context of experimental games.

Reviews on index insurance conclude that there is a prevalent knowledge gap on the ex post impacts of index insurance (Miranda and Farrin 2012, Carter et al. 2014). We are aware of only one existing study, by Janzen and Carter (2013), that explores the effectiveness of insurance indemnity payments in the aftermath of a weather shock. Janzen and Carter focus on an index-based livestock insurance pilot scheme in the Marsabit district of northern Kenya. The authors analyze the impact of indemnity payments triggered by a severe drought in 2011, using randomly distributed information and price discounts to identify selection into purchasing insurance. The majority of insured Kenyan households purchased index insurance under subsidized rates. The outcome of interest is households' anticipated use of shock coping strategies in the next quarter of the year. This information is recorded during the drought, but before the insurance indemnity payments are transferred to households. Janzen and Carter find that insurance indemnity payments significantly affect the choice of coping strategies that households expect to use: Insured households are less likely to anticipate selling livestock and reducing meals compared to non-insured households. Moreover, the authors distinguish between households below and above a critical asset threshold. Insured households below the asset threshold are less likely to expect reducing the number of meals, while insured households above the threshold are less likely to expect selling livestock. Our study builds on the findings of Janzen and Carter (2013) by investigating the observed post-shock asset dynamics of Mongolian herders after receiving insurance indemnity payments. 


\section{Empirical context}

\subsection{Herding and weather risk in Mongolia}

Herding is the main economic activity in rural Mongolia. It is the single most important employment sector, accommodating about 35 percent of the workforce in 2012 (NSO 2013). Most households living outside the capital of Ulaanbaatar own livestock, with approximately 146,000 households consisting of about 545,000 individuals (about 19 percent of the population) deriving their livelihood from herding (ibid.). Extensive production techniques are commonly used in herding, with animals being grazed on open rangelands that are in state property. The majority of herders is nomadic or semi-nomadic and moves their herds between two and 25 times per year; most herders follow similar annual movement patterns, usually returning to the same campsites every year. Herders typically own a mix of five species that are adapted to the extreme continental climate of Mongolia: sheep, goats, horses, cattle and camel. Sheep provide most of the meat for households' subsistence needs as mutton is the preferred type of meat. Cattle primarily provide milk that is consumed and used for other dairy products. Cashmere wool derived from goats is an important source of cash income. Horses and camels are mainly used for tending smaller livestock and for transportation; they are also considered a prestigious form of storing wealth. All animal species are sold (alive, slaughtered, as well as their skins and hides) if need arises. In 2012, herding households owned on average 244 animals (NSO 2013). The national herd was estimated at 35.7 million animals (ibid.).

Mongolian herders face a number of risks and hazards that pose a constant threat to their livelihood. The most prevalent risk is extreme winter conditions, called $d z u d$ in Mongolian, which cause mass livestock losses. Dzuds are triggered by various and rather different climatic conditions, often by a combination of several. Among them are too little precipitation (either in the preceding summer or during the winter) that limits vegetation growth; excessive snowfall that prevents animals from grazing; extremely cold temperatures that sharply raise the calories intake required by animals; and fluctuations in winter temperatures above and below freezing that lead the snow to melt and then ice over, thus making it difficult for animals to reach the grass (Batima 2006, p.57; Murphy 2011, p. 32-33). Dzuds are reinforced by local geographic features, such as the ecological zone, altitude, and the location on a slope, thus making it difficult to predict when and where dzuds will occur. Since 1990, dzuds occurred in the winters of 1999/00, 2000/01, 2001/02, and 2009/10.

Our focus in this paper is on the dzud of 2009/10, which caused the highest livestock mortality in a single winter ever recorded in Mongolia. This point is illustrated in Figure 1, which presents livestock dynamics in the three survey provinces of Uvs, Zavkhan and Govi-Altai of western Mongolia between 1970 and 2014, calculated from annual livestock census data. Two aspects are noteworthy. First, the 2009/10 dzud pushed livestock numbers back to mid-1980s levels. Thus, a single catastrophic winter was enough to eliminate decades of livestock development. Second, there was a rapid and steady recovery in livestock starting in 2010. By 2014, livestock levels had almost reached 2009 levels.

The socio-economic consequences of the 2009/10 dzud were numerous. Some 40 percent of all herding households lost more than half of their herd (UNDP and NEMA 2010, p. 41). Many households were pushed below the herd size of 100 animals, which is considered the minimum necessary for sustaining a pastoralist livelihood in the long term. A sizeable number of impoverished herders moved as distress migrants to urban centers in search of employment (Sternberg 2010). The food security of severely af- 
fected households was threatened (IFRC and MRCS 2010). In turn, malnutrition experienced during the dzud months had lasting impacts on the health of children from herding households: Children who lived in severely affected regions were significantly shorter three years after the dzud compared to same-aged children living in less affected regions (Groppo and Schindler 2014).

While both the government and international agencies provided emergency aid to dzud-affected regions in 2010, this support has been ad hoc and did not reach all of the affected herders in the sparsely populated countryside (UNDP and NEMA 2010). When the 2009/10 dzud hit Mongolia, formal financial markets were only starting to develop in rural areas (Goodland et al. 2009). Thus, herders mainly drew on informal strategies to manage risk and cope with the consequences of the dzud (Fernández-Giménez et al. 2015). Increasing the herd size was the most important informal risk management strategy to prepare for harsh dzud winters (Goodland et al. 2009). Other common strategies applied in the midst of dzud winters include conducting additional nomadic movements and providing animals with supplementary fodder (mostly hay) (Murphy 2011; Fernández-Giménez et al. 2015). Yet, given the severity and covariate nature of dzuds, the effectiveness of informal risk management mechanisms is limited. As a consequence, "high levels of livestock mortality are often unavoidable even for the most experienced herders" (Mahul and Skees 2007, p. 10). After dzud, restocking is the most important goal for herders (Goodland et al. 2009).

\subsection{Index-Based Livestock Insurance Mongolia}

After three consecutive dzud winters between 1999 and 2002, there was consensus among policymakers in Mongolia that herders needed effective and sustainable insurance against livestock losses caused by dzuds (Mahul and Skees 2007). The Government of Mongolia requested assistance from the World Bank to create a livestock insurance scheme that suited the characteristics of the Mongolian herding sector. The World Bank proposed the Index-Based Livestock Insurance that would be offered to herders as a commercial product by private insurance companies (Skees and Enkh-Amgalan 2002).

In 2006 IBLI was introduced as a pilot project in three - Bayankhongor, Khentii, and Uvs - out of the 21 provinces of Mongolia (see the map in Figure 2). During the pilot phase, the Project Implementation Unit (PIU) of IBLI played a key role in organizing and marketing the insurance as well as in supporting insurance agents selling actual IBLI policies. Insurance uptake rates increased steadily over the pilot phase and were well over 20 percent in some provinces (Hartell 2011, p. 27). After the encouraging performance during the pilot phase, IBLI was stepwise scaled up to the national level until 2012. IBLI has since been offered in every district of Mongolia. In 2014, all PIU activities were handed over to the participating private insurance companies and the provincial PIU offices were closed. At the same time, a reinsurance company with public-private ownership was established to serve as reinsurer for the private sector insurance companies selling IBLI (Law of Mongolia 2014).

The key objective of IBLI is 'to reduce herders' livelihood vulnerability caused by dzud or natural disasters"(PIU 2012, p. 12). In more general terms, IBLI aims at improving herders' welfare by increasing herd size, assets, savings, and income from both herding and non-herding activities (Hartell 2011, p. 11). Under IBLI, indemnity payments are made to insured herders when the district-level mortality rate of a given livestock species exceeds the threshold of 6 percent 1$]$ Herders receive indemnity payments

\footnotetext{
${ }^{1}$ Two data sources are used to calculate livestock mortality rates: First, the total number of adult animals is obtained
} 
irrespective of the actual losses they personally experienced (which would be very costly to verify, given the vast distances in Mongolia's countryside). Moderate losses that fall below the 6 percent threshold are not covered by IBLI and remain the responsibility of the herders alone. This feature ensures that herders continue implementing informal risk management strategies, thus discouraging moral hazard (Hartell 2011). More severe shocks resulting in livestock loss rates above the 6 percent threshold trigger IBLI indemnity payments, which are paid from a joint-liability pool of the participating private insurance companies. One challenge inherent in the nature of dzuds is that extremely severe shocks occur every now and then. Such catastrophic covariate events are likely to trigger indemnity payments in many districts, which may render local insurance companies bankrupt. In order to make IBLI sustainable in the long term, the government and global reinsurance companies provide additional cover if indemnity payments if mortality rates exceed 6 percent.

For herders, participation in IBLI is voluntary. There are several features inherent in IBLI that allow herders to customize the insurance contract to their needs. Premium rates differ across districts and species, reflecting the local livestock mortality risk. Hence, the insurance contract is signed for a prespecified district. Pastoralist households follow customary movement patterns, but usually stay at the same campsite during the winter when approximately 90 percent of the losses occur (Mahul and Skees 2007). Herders can choose purchasing IBLI for any of the five common livestock species; for instance, herders can insure only horses, but not their cattle. Herders also decide on the insurance value for each species, which can be between 1 and 100 percent of the animals' market value. Incomplete insurance is prevalent, with herders insuring on average only 30 percent of the value of their herd (PIU 2012) $!^{2}$

Local insurance agents representing the (currently) six Mongolian insurance companies participating in the IBLI program sell IBLI policies to herders. IBLI policies are sold between April and June in a given year and cover livestock losses occurring between December and June of the following year. Given that the sales period ends in mid-summer, neither herders nor insurance companies can predict conditions in the next winter, which prevents adverse selection. Indemnity payments are made to insured herders from August the following year onwards. The processing of insurance premiums and indemnity payments is done via local banks. Some banks also offer loans with discounted interest rates to insured herders (PIU 2012).

Our focus in this paper is to explore if IBLI helped insured households cope with the catastrophic dzud of 2009/10, which occurred while IBLI was still in its pilot phase. In 2009, IBLI was available to herders in four provinces, including the province of Uvs in which the household survey was implemented. In Uvs province, 1,835 herders purchased IBLI in 2009, representing an uptake rate of 19.5 percent (PIU 2012) 3

from the yearly livestock census, which has been implemented since the 1920s. Every year in mid-December, the National Statistical Office of Mongolia (NSO) gathers data on the national stock. This exercise is carried out collaboratively by enumerators and local officials, who maintain detailed records of herders and their livestock in their administrative division. Second, in June of each year, the NSO conducts a livestock survey to establish the losses of adult animals due to dzud during winter and spring. From the two data sources, the district-level mortality rates of adult animals are then calculated separately for each species.

${ }^{2}$ For example, a herder in Tunel district of Khuvsgul province wishes to insure his 18 horses under IBLI: The market value for a horse in Khuvsgul is 225 US\$ and the IBLI premium rate for a horse in Tunel district is 1.69 percent. The total livestock value is $18^{*} 225 \mathrm{US} \$=4,045 \mathrm{US} \$$. If the herder decides to insure his horses at 100 percent market value, the insurance premium would be 1.69 percent $* 4,045$ US $\$=68$ US $\$$. Imagine the district-level mortality of horses in Tunel district is 15 percent in the following winter. Then the indemnity rate would be 15 percent- 6 percent=9 percent. The herder would receive an indemnity payment of 9 percent $* 4,045$ US $\$=364$ US $\$$ (example taken from PIU 2012, p. 48).

${ }^{3}$ The household survey data comprise 261 herding households that lived in Uvs in 2009, of which 59 households purchased IBLI. Thus, the IBLI update rate in our sample of 22.6 percent corresponds closely to the actual uptake rate in the population. 
On average, herders in Uvs province insured 102 heads of livestock and paid an insurance premium of 28,000 Mongolian Tugrik (MNT) (about 19 US\$) (ibid.). The losses in the winter 2009/10 triggered indemnity payments to 95.4 percent of insured herders in Uvs province, who received on average 416,000 MNT (about 312 US\$) as indemnity payment (ibid.). The large overall amount of indemnity payments that were triggered by the 2009/10 dzud posed a challenge for the sustainability of the IBLI scheme. Additional support from the World Bank and other donors was necessary to stem the extremely high amounts of indemnity payments after the 2009/10 dzud disaster ${ }^{4}$

\section{Data}

Our analysis builds on three waves of the Coping with Shocks in Mongolia Household Panel Survey that is implemented by the authors in collaboration with the National Statistical Office of Mongolia (NSO). The survey data are collected in the three neighboring provinces (aimags) of Uvs, Zavkhan, and Govi-Altai in western Mongolia (see Figure 2 the survey provinces are bold-rimmed) and cover 49 out of 61 districts (soums) in these three provinces 5 Compared to other regions of Mongolia, the three survey provinces resemble each other in terms of socio-economic characteristics of the population, economic activities, and the large distance to the capital Ulaanbataar, which is a good proxy for access to urban markets and economic opportunities.

The survey sampling is based on the Population and Housing Census of 2010 and uses a multi-stage design, which ensures that the sample is representative of the population in western Mongolia $\sqrt{6}$ More specifically, statistically significant results are achieved for each of the three survey provinces, for urban areas in each province, and for rural areas in each province. The sampling design was not influenced in any way by the purpose of conducting an impact study of IBLI. Rather, the aim of the survey was to gather representative data of the population in the region, which underlines the robustness of our results. The first, second, and third panel waves were collected between June 2012 and May 2013, between June 2013 and May 2014, and between June 2014 and May 2015, respectively. For the sake of readability, we identify variables collected in the first, second, and third panel waves as 2012, 2013, and 2014. Household interviews were conducted continuously throughout the year, with one-twelfth of the sample households interviewed every month. The data are representative across seasons.

The sample comprises 1,094 households owning livestock in 2009. All sample households that purchased

\footnotetext{
${ }^{4}$ As a result of the 2009/10 dzud, the insurance product was slightly revised. Until 2010, herders could choose between the Disaster Risk Product (DRP), which covered only catastrophic losses above a threshold of 30 percent, and the Base Insurance Product (BIP), which covered all losses above the triggering threshold of 6 percent (Mahul and Skees 2007 Miranda and Farrin 2012). After the 2009/10 dzud, the DRP was abolished both due to low uptake and unsustainable reinsurance arrangements. The BIP was transformed into the so-called Livestock Risk Insurance (LRI), which covers losses above the 6 percent and the 30 percent threshold within one product (DeAngelis 2013). In the analyses presented in the following, we do not distinguish between herders buying DRP or BIP in 2009.

${ }^{5} \mathrm{~A}$ province is the top level of Mongolia's administrative structure. Each province is subdivided into several districts (soums), which are further subdivided in sub-districts (bags). There are 21 provinces, 329 districts, and 1,720 sub-districts in Mongolia. As of 2011, districts in western Mongolia have an average population of 3,154 persons and a size of 4,811 square kilometers.

${ }^{6}$ In the first sampling step, the three provinces were subdivided into nine mutually exclusive strata of province centers, district centers, and rural areas. In the second step, Primary Sampling Units (PSU) were randomly drawn from each stratum, resulting in a total number of 221 PSUs. In a third sampling step, inside each PSU eight households were randomly selected. Unfortunately, the matching estimator as well as other propensity score estimators that we draw upon do not allow to account for survey design effects and the clustering of standard errors (cf. Guo and Fraser 2010, p. 243). To assess the impact of design effects, we estimate two versions of our main specification with OLS: one simple version and one version that accounts for design effects and clustering of standard errors. Results (available upon request) are almost identical, which makes us confident that this issue is less of a concern.
} 
IBLI in 2009 reported experiencing the 2009/10 dzud and all of them were still herders when the household survey was implemented. To ensure that the group of non-insured control households is comparable to the insured treated households, we exclude 125 control households that reported not being exposed to the dzud and 118 control households that lost their entire herd during the 2009/10 dzud and dropped out of the herding economy in the aftermath of the dzud. Moreover, we exclude all 206 non-insured households living in the province of Uvs 7 Lastly, we exclude 3 control households with missing values in key covariates. This leaves us with a sample of 642 herding households.

The survey questionnaire collects detailed information on the demographics of each household member, household consumption expenditures, income, assets, subjective well-being, social networks, livestock holdings, strategies in herding as well as infrastructure and environmental conditions in the district. One questionnaire module focuses specifically on households' exposure to the 2009/10 dzud and post-dzud coping strategies applied.

Another questionnaire module records detailed information on IBLI from all herding households. This module asks for retrospective information on the purchase of IBLI in the past. More specifically, information is available on whether the household purchased IBLI in 2009, the amount of indemnity payments received in 2010, how indemnity payments were used, and whether the household found the indemnity payments helpful 8 It is important to note that the treatment variable in our analysis - whether a household had purchased IBLI in 2009 - is recorded twice in two separate modules of the questionnaire (in the module on IBLI and in the module on the 2009/10 dzud). All but two treated households gave consistent answers on their insurance status in 2009 in these two modules, which underlines the reliability of the treatment variable. Our sample comprises 59 treated households and 583 control households.

The key variable in our analysis is households' livestock holdings at five points in time: in 2009 (before the shock) as well as in 2011, 2012, 2013, and 2014.9 In each of the three panel waves $(2012,2013$, 2014), households are asked about their current livestock holdings at the time of the survey interview. The livestock holdings in 2011 are obtained from the first panel wave, when households were asked to also report detailed changes in livestock holdings during the previous 12 months. The livestock holdings in 2009 (and also livestock losses experienced during the dzud, which is included as covariate in our multivariate analysis) are asked retrospectively from households.

Two empirical observations make us confident that the retrospectively recorded information on past livestock holdings is reliable. On the one hand, households are asked about their livestock holdings in 2009 and dzud-related livestock losses twice, in the first panel wave and again in the third panel wave. The coefficient of correlation for livestock holdings in 2009 recorded in the first and third wave is 0.79 ; the coefficient of correlation for livestock losses is 0.83 . Our preferred measure is retrospective information recorded in the first panel wave, given that the recall period is shorter. As a robustness test, we carry out all estimates with retrospective information recorded in the third wave and obtain very similar results (as will be discussed in section 6.3). This test assures us that the retrospectively recorded variables are of

\footnotetext{
${ }^{7}$ We exclude non-insured households in Uvs province who had access to IBLI in 2009 to control for a part of the unobservable factors determining the purchase decision and to eliminate potential spill-over effects in our estimates (see discussion in section 5. The results hold when including non-insured households living in Uvs province in the analysis.

${ }^{8}$ Unfortunately, information is not available on the number and species of livestock insured in 2009 and on the amount of insurance premium paid in 2009.

${ }^{9}$ Household interviews for each panel wave were carried out over a period of 12 months, starting in June of each year. To ensure comparability in herd size across households interviewed before and after the birthing season, we exclude newborns from households who were interviewed during the birthing season (between January and May).
} 
good quality. On the other hand, anthropological studies on Mongolia stress the importance of livestock holdings for the social standing of households. According to Murphy, "being wealthy in livestock, to be myangat or bayan, carries additional symbolic power beyond the economic value of the herd. It is more than being ix maltai (having many stock)" (Murphy 2011, p. 132). For instance, there are specific terms in the Mongolian language to classify herders with different livestock holdings ( $<100$ heads; 100-200; 200500; 500-1,000; and $>1,000$ heads) (ibid.). Therefore, it is not surprising that our survey enumerators did not observe difficulties among respondents to recall the size of their herd in the past. In fact, the questionnaire also asks for livestock holdings even further back in time (for instance, in 1990, 1999, and 2002), which respondents also reported without difficulty.

Complementary to the household survey data, we employ aggregated data from the Mongolian livestock census, which is implemented annually in mid-December by the NSO. More specifically, we use data on adult livestock mortality in 2010 at the level of the sub-district.

\section{$5 \quad$ Identification strategy}

The aim of our analysis is to explore the causal effects of receiving IBLI indemnity payments in 2010 on households' post-disaster livestock recovery. We need to tackle the problem of missing data on the counterfactual: What would livestock recovery of insured households have been in the absence of indemnity payments? The IBLI scheme was implemented without randomized assignment rules at the household level. Thus, our empirical strategy needs to account for selection into treatment. All 59 households in our sample that purchased IBLI in 2009 also received indemnity payments in autumn 2010. Therefore, the treatment is an indicator variable taking the value one if a household purchased IBLI in 2009. Our identification strategy exploits the phasing-in of IBLI, with IBLI initially available in only one of the three survey provinces in 2009. The treated sample households all live in the province of Uvs, whereas control households live in the provinces of Zavkhan and Govi-Altai, where IBLI was introduced only after the dzud winter. We then employ matching methods to simulate a counterfactual.

More specifically, we employ the bias-corrected matching estimator (Abadie and Imbens 2002, 2006, 2011) to account for selection into purchasing IBLI in 2009 based on observable characteristics. The matching estimator uses a vector norm to impute a counterfactual outcome for each sample household (both the treated and non-treated). The vector norm calculates distances on the covariates between a treated household and each of its potential control households and vice versa (Guo and Fraser 2010, p. 212). Then the outcomes of households of the other treatment status that exhibit the shortest distance in covariates - the nearest-neighbors - are imputed as counterfactual outcomes to each household.

Formally, for each household $h$ we know one of the potential outcomes, namely $Y_{h}(1)$ for those who purchased IBLI in 2009 and $Y_{h}(0)$ for those who did not. If a household purchased IBLI $\left(T_{h}=1\right)$, we use its observed outcome $Y_{h}$ as its estimated outcome under treatment, such that $Y_{h}=Y_{h}(1)=\tilde{Y}_{h}(1)$. If a household did not purchase IBLI (and therefore has not received indemnity payments) $\left(T_{h}=0\right)$, we use the observed $Y_{h}$ as our estimate under non-treatment, with $Y_{h}=Y_{h}(0)=\tilde{Y}_{h}(0)$. To derive the estimates of the counterfactual outcomes, the matching estimator imputes the non-observed outcomes for each household $h$ using the average of the outcomes of the $M$-closest households in the opposite treatment group $J$. The estimated outcomes in the treatment $\tilde{Y}_{h}(1)$ and the non-treatment $\tilde{Y}_{h}(0)$ case are then 
estimated as simple matching estimator (Abadie and Imbens 2002):

$$
\begin{aligned}
& \tilde{Y}_{h}(1)=\left\{\begin{array}{lll}
\frac{1}{M} \sum_{j \in J_{M}(h)} Y_{j} & \text { if } & T_{h}=0 \\
Y_{h} & \text { if } & T_{h}=1
\end{array}\right. \\
& \tilde{Y}_{h}(0)=\left\{\begin{array}{lrr}
Y_{h} & \text { if } & T_{h}=0 \\
\frac{1}{M} \sum_{j \in J_{M}(h)} Y_{j} & \text { if } & T_{h}=1
\end{array}\right.
\end{aligned}
$$

Our set of covariates includes several continuous covariates (discussed below), which would result in inaccurate matching and lead to biased estimates (see Abadie and Imbens 2006 for a discussion). Therefore, we additionally include a bias-correction term when imputing the counterfactual outcomes. The bias correction is based on a linear regression of $Y_{j}$ on the covariates $X_{j}$ of the $M$-closest control observations $j$. It adjusts the counterfactual estimates for the differences in the covariate values for each observation $X_{h}$ with its matched observations from the opposite treatment group $X_{j}$. Matching is done with replacement: Each household is matched to several households of the opposite treatment status. This feature maximizes the number of matches used in the analysis and is thus well-tailored to the small number of treated households in our empirical setting. We match each household with four households $(M=4)$ of the other treatment status, following recommendations by Abadie et al. (2004) ${ }^{10}$ We estimate the impact of indemnity payments as sample average treatment effect (ATE) ${ }^{11}$

The matching estimator has several advantages over alternative methods to account for self-selection into treatment (Guo and Fraser 2010): Matching with replacement leads to matches of higher quality; a consistent estimator is available to estimate variance; no assumptions on the functional form of the covariates are required; and no post-matching analysis needs to be carried out. This, however, might come at the expense of less precision (Abadie and Imbens 2006; Guo and Fraser 2010).

The matching estimator relies on the following three key assumptions: First, it assumes that the selection into treatment is independent of the outcome after controlling for observed covariates (i.e., the ignorable treatment assignment assumption holds). If there are remaining unobservables that are correlated with both treatment and outcome, the matching estimator yields biased estimates. As we cannot exploit any household-level randomization in the implementation of IBLI, we are unable to control explicitly for selection based on unobservables. Yet, exploiting the phasing-in of IBLI allows us to partly account for selection based on unobservables. Non-treated households in Uvs province (where IBLI was available in 2009) are excluded from the sample, while the control group consists only of households living in provinces where IBLI was not available in 2009. This way, we increase the likelihood that treated and control households share similarities in unobserved characteristics. Moreover, our household survey data include an unusually large number of pre-shock and time-invariant variables that we include as covariates in our estimations. Given that at least some of the unobserved characteristics are likely to be correlated with observed characteristics, we hope to keep this bias to a minimum.

The second assumption requires a sufficient overlap in the distribution of covariates between treated and

\footnotetext{
${ }^{10}$ The estimations were carried out using the teffects nnmatch command in Stata. The Breusch-Pagan and Cook-Weisberg tests for heteroscedasticity reject the null hypothesis of constant variance for most covariates. Therefore, we specified a robust variance estimator allowing for heteroscedasticity. As variance matrix, we use the inverse of the variance-covariance matrix, with the Mahalanobis metric used to calculate distances.

${ }^{11}$ The ATE calculates the average treatment effect of indemnity payments on all herding households in our sample. The choice to report the ATE reflects the fact that IBLI aims at targeting all herding households, uptake rates are relatively high, and IBLI has been scaled-up to the national level in the meantime.
} 
non-treated sample households. When the overlap condition is fulfilled, each household has a positive probability of receiving each treatment level. We use propensity score methods to investigate the overlap for three sets of covariates (explained later on in this section). Figure 3 shows that the overlap in the propensity scores is sufficient for all three sets of covariates. It is quite large for the minimal set (Figure 3a) and the core set of covariates (Figure 3b) and still acceptable in the maximal set of covariates (Figure 3c).

Third, the estimated coefficient of the treatment variable only reflects the true effect if the stable unit treatment value assumption (SUTVA) holds. The potential outcome of each household needs to be independent of the potential outcomes of all other households. This assumption would be violated if indemnity payments were distributed within herder' networks, for instance within the family or across households that share a campsite. Such patterns could lead to general equilibrium effects that may affect the post-shock recovery of all households - also of the non-insured. Our study minimizes the possibility of a violation of SUTVA by exploiting the phasing-in of the IBLI scheme across provinces.

We employ two types of outcome measures, with each defined for several years. First, we use post-disaster livestock numbers in the years 2011, 2012, 2013, and 2014. Second, we use livestock growth rates, which explicitly take into account the pre-shock herd size. More specifically, we construct the cumulative annual livestock growth rates ${ }^{12}$ in the periods 2009-2011, 2009-2012, 2009-2013, and 2009-2014.

We employ three sets of covariates when estimating the effect of IBLI indemnity payments on post-shock livestock recovery. This way, we account for the fact that the choice of covariates can influence the estimated results when using methods that correct for self-selection into treatment (Guo and Fraser 2010). The full list of control variables and summary statistics are displayed in Table 1

The first set of covariates is informed by a probit estimation of the determinants of purchasing IBLI in 2009 (Table 2). The sample consists of all herding households living in the province of Uvs in 2009. Of the various controls included, only households' livestock holdings in 2009 and the local ecological zone in the district have a statistically significant effect on the purchase decision. This result is in line with our expectations and suggests that it is primarily exposure to risk factors that influence the uptake of IBLI: Households with large herds have fewer alternative income sources and are, thus, more vulnerable to livestock losses. The ecological zone is a good proxy for the long-term risk of experiencing a dzud. In column 2 , we additionally include district fixed effects, which control most comprehensively for any differences related to the supply of IBLI and the risk of facing dzud across districts. Livestock holdings in 2009 remain the only significant predictor for purchasing IBLI in 2009. Based on these findings, the first set of covariates (referred to as minimal set of covariates of covariates below) comprises households' livestock holdings in 2009 as well as characteristics of the local ecological zone. Moreover, we include in the minimal set of covariates the number of livestock lost during the 2009/10 dzud as self-reported by households.

The second set of covariates (referred to as core set of covariates below) additionally consists of variables that are also identified by the existing theoretical and empirical literature on index insurance to explain selection into purchasing insurance. For instance, empirical studies by Cole et al. (2014) and Giné et al. (2008) find that wealth and liquidity are important determinants of index insurance uptake in

\footnotetext{
${ }^{12}$ The cumulated growth rate is a geometric progression ratio. For instance, the 2009-2012 livestock growth rate is defined as livestock $2012^{\frac{1}{3}}-1$. It represents the average annual growth rate, assuming that livestock dynamics were constant across years. This definition is commonly applied in the financial economics literature, e.g. when calculating expected average returns of investments over time (Feibel 2002).
} 
India and Kenya, respectively. We account for these factors by controlling for pre-shock herd size, which is both the most adequate measure of wealth among herders and a suitable proxy for cash income from agriculture 13 Moreover, we utilize households' subjective relative well-being in 2009. More specifically, households are asked to rank their socio-economic position just before the 2009/10 dzud started relative to other households in their district on a scale from 0 to 10. Compared to other studies based on observational data, the availability of retrospective information on wealth is a unique feature of the data at hand.

Attitude toward risk is also identified as a key factor influencing the decision to purchase index insurance (Clarke 2011 Cole et al. 2014). Hence, we account for the risk attitude of the head of household. The survey questionnaire asks respondents to indicate their general willingness to take risk on a 0-10 scale ${ }^{14}$ Furthermore, Gaurav et al. (2011) show that financial literacy matters for the decision to insure, given that index insurance is a complex financial product. We proxy financial literacy with the education and age of the head of the household.

Lastly, shock intensity and shock coping opportunities are important predictors of recovery (Janzen and Carter 2013). In addition to the household-level shock measure, we use livestock mortality in 2010 at the sub-district level (calculated from livestock census data) to proxy for the covariate nature of the dzud. An indicator variable taking the value one if households live in rural areas (as opposed to district centers and provincial centers) proxies income opportunities outside the herding economy. At the district level, the availability of cellphone networks and the number of public transportation options to the provincial capital are employed to capture differences in economic access and hence in opportunities for post-dzud recovery across districts ${ }^{15}$

The third set of covariates (referred to as maximal set of covariates below) additionally includes three controls that proxy households' ability to cope with dzud. These include the percent of female breeding stock out of total herd size and the number of economically active household members. During a harsh winter, the demand for labor in herding activities increases. For instance, livestock needs to be tended more closely and moving the herd to areas less affected by the dzud is highly labor intensive. In addition, we employ an indicator variable taking the value one if a household knows the local sub-district governor very well. A household that maintains close ties to the local governor might have a larger social network within the community and thus more options at hand to receive support (both informal and formal) following the dzud. While these three variables capture important differences across households, they entail one limitation: All three variables refer to 2012, the time of the first panel interview, which makes them potentially endogenous to the household-level shock exposure. Therefore, their inclusion as covariates may be disputable.

One potential concern in our analysis is that non-treated herders may have been exposed to a higher dzud intensity in the 2009/10 winter than the treated households (Hartell 2011). If treated households faced less severe dzud conditions in the winter 2009/10 and hence had more favorable circumstances for post-dzud recovery than non-treated households, we would falsely attribute their faster post-disaster recovery to IBLI indemnity payments. We undertake three measures to minimize this concern. First, recall

\footnotetext{
${ }^{13}$ In 2012 , the coefficient of correlation between herd size and household cash income from herding was 0.68 .

${ }^{14}$ This way of eliciting risk preferences in survey interviews was first used in the German Socio-Economic Panel (Dohmen et al. 2011). Recent studies demonstrate that this measure also works reasonably well as a control variable in studies in developing countries (Hardeweg et al. 2013 . Nielsen et al. 2013).

${ }^{15}$ Variables on district-level infrastructure refer to 2012 , when the first survey interview was conducted. We thus have to assume that conditions were constant between 2009 and 2012 .
} 
that our estimations include controls for the intensity of the 2009/10 dzud at the household level and the sub-district level. Second, we explore whether treated and control households differ in the number of livestock lost during the dzud after controlling for observable household and district characteristics. Results of an OLS estimation of the determinants of livestock losses due to the dzud are displayed in Table 3 . The estimated coefficient of purchasing IBLI in 2009 is not statistically significant. Hence, there is no indication that treated and control herders experienced a statistically different shock intensity. Third, we explore the spatial variation in dzud intensity across sub-districts. Figure 4 shows the livestock mortality in 2010 in sub-districts included in the household survey. Clearly, the variation in dzud intensity within each province is very large: in each province, there are sub-districts experiencing low livestock mortality (below 17 percent) and high livestock mortality (above 50 percent).

\section{Results}

\subsection{Testing for balance in covariates}

First of all, we explore the balance in covariates across treated households (who purchased IBLI in 2009) and non-treated households (who did not purchase IBLI in 2009). Table 4 displays mean values and tests on differences in means. Most importantly, treated and control sample households do not differ significantly in their pre-shock herd size. The average number of livestock in 2009 was 349 animals among treated herders and 309 animals among control herders. During the 2009/10 dzud, treated herders lost 130 animals, compared to 143 animals lost among control herders. Again, this difference in losses caused by the shock is not statistically significant for treated and control herders. Thus, it is reassuring that treated and control households exhibit similar characteristics in the key covariates in our analysis. This also holds for characteristics of the local ecological zone, which correlate strongly with the long-term dzud risk. Similarly, treated and control households share very similar levels of education and age of the head of household, as well as female breeding stock among their animals in 2012. Treated and control households live in districts that share similar characteristics in transport infrastructure.

However, several other covariates exhibit statistically significant differences across treated and control households. For instance, treated households have a significantly higher likelihood to live in rural areas, judged their relative subjective wellbeing in 2009 to be higher, and are more risk averse than non-treated herders. Treated households tend to live in areas that exhibit, on average, a significantly lower livestock mortality in 2010. Furthermore, treated households are significantly less likely to know the governor in their sub-district very well and they have significantly more economically active household members. To conclude, assignment to treatment is not ignorable and without controlling for selection into purchasing IBLI in 2009, estimated effects of receiving IBLI indemnity payments would be biased.

\subsection{The effect of IBLI indemnity payments on recovery}

Next, we employ the bias-corrected matching estimator to assess the impact of IBLI indemnity payments in 2010 on post-disaster livestock recovery. Table 5 shows average treatment effects for eight different outcome variables. Panel A, B and C display results when using the minimal, core and maximal set of covariates, respectively. 
Results show an overall positive effect of IBLI indemnity payments on post-disaster livestock recovery after controlling for selection based on observables. Herders who purchased IBLI in 2009 and received indemnity payments in 2010 have a larger herd size in 2011, 2012, and 2013 compared to herders who did not purchase IBLI (Table 5, columns 1-3). The treatment effect is strongest for livestock holdings in 2012, with all three sets of covariates yielding statistically significant results. For livestock holdings in 2013, the treatment effect is only marginally statistically significant at the 13 percent level for the core set of covariates (panel B), while the treatment effect is no longer significant for the minimal set of covariates (panel A) and the maximal set of covariates (panel C). For livestock holdings in 2014 (column 4), the treatment effect is still positive, but no longer statistically significant for any of the three sets of covariates.

The magnitude of the treatment effect is relatively large: In 2011, treated households own on average 15 to 16 percent more livestock than control households; in 2012, they own between 22 percent and 27 percent more livestock; and in 2013, they own about 17 percent more livestock ${ }^{16}$ This corresponds to a difference in herd size between treated and control herders of about 20, 32, and 27 animals in 2011, 2012, and 2013. Thus, the positive effect of indemnity payments appears to attenuate three years after the shock 17

These results are confirmed when focusing on the cumulative annual livestock growth rates as outcome variables (Table 5, columns 5-8). Again, receiving IBLI indemnity payments in 2010 has a positive and significant effect on post-disaster livestock dynamics through 2011, 2012 and 2013. This finding is strongest for the core set of covariates (panel B), while the minimal and maximal set of covariates (panels A and C) only yield significant results for the period 2009-2012. On average, treated herders have an annual livestock growth rate that is about 4 to 5 percentage points higher compared to control households when considering the time periods 2009-2011 and 2009-2012; and for the entire 2009-2013 period it is about 3 percentage points higher.

As a refinement, we investigate whether the positive effect is homogenous across different levels of indemnity payments received. We exploit information on the amount of indemnity payments received in 2010 as self-reported by respondents. Treated households in our sample reported receiving indemnity payments between 38,000 MNT (28 US\$) and 1,300,000 MNT (974 US\$), with the average being 268,000 MNT (201 US\$). This is considerably lower than figures from official PIU records, which report that households in Uvs province received on average 416,000 MNT (312 US\$) as indemnity payments in 2010 (PIU 2012). Thus, underreporting appears likely among the survey households. Therefore, we opted for distinguishing between three doses of treatment: receiving no indemnity payments (non-treated households), receiving indemnity payments below the 25 th percentile (up to 120,000 MNT (90 US\$)), and receiving indemnity payments above the 25th percentile. We focus on the recovery period until 2012, which provided the most robust results in the baseline estimation 18 Results in Table 6 show that the estimated coefficients of both high and low doses of treatment are at least marginally significant. This holds when both using

\footnotetext{
${ }^{16}$ Since the outcome is log transformed, the magnitude of the treatment effect is derived by calculating the exponentiated value of the estimated coefficient. Note that the percent changes refer to the geometric mean of livestock numbers. We only consider coefficients that are at least marginally significant.

${ }^{17}$ The corresponding effect in terms of absolute livestock numbers is calculated as the difference between the exponentiated geometric mean of the control group and the exponentiated geometric mean of the treatment group as derived from the estimated treatment effect.

${ }^{18}$ The matching estimator does not allow for estimating different doses of treatment. Therefore, we apply a two-step procedure (Imbens 2000) that uses in a first step a multinomial logit estimation on the selection into treatment to derive generalized propensity scores for each treatment status. In a second step, the inverse of the propensity scores is used as sampling weight in an OLS estimation on the outcome variable (see for a detailed explanation Guo and Fraser (2010. p. 166-167).
} 
livestock holdings in 2012 and cumulative livestock growth rates in the period 2009-2012 as outcome variables. In both estimates, the estimated coefficients of high doses of treatment are larger in magnitude (although the difference is not statistically significant), suggesting that the positive effect of treatment is more pronounced for treated households that received high indemnity payments. This could indicate that there might be a minimum insurance coverage needed for positive effects to unfold.

\subsection{Robustness tests}

We conduct various tests on the sensitivity of results to model assumptions. First, the estimated treatment effect derived from the matching estimator is sensitive to the number of matches chosen for each unit (Abadie et al. 2004). The bias due to inexact matches is likely to decrease with a larger set of matches (Abadie and Imbens 2006, p. 240). While we use four matches in our baseline estimations, Table 7 shows results when using two and six observations for each match. Results are not sensitive to the number of matches. The magnitude of the estimated treatment effect slightly increases when a larger number of matches is used.

Second, we employ two alternative propensity score estimators that correct for self-selection into treatment based on observables (Table 8): the inverse probability-weighted regression adjustment (IPWRA) (panel A) and the augmented inverse-probability weighting (AIPW) (panel B). Both methods comprise a two-step procedure, estimating first selection into treatment, and in a second step the outcome. The estimators are double-robust, as the estimated coefficients are robust to misspecifications in one of the two regressions (Wooldridge 2007: 2010). Results confirm the positive and significant effect of IBLI indemnity payments on post-disaster recovery until 2012. Overall, the magnitude of the treatment effect is slightly smaller compared to results from the matching estimator. The average treatment effect on livestock holdings in 2012 is 0.19 (IPWRA) and 0.21 (AIPW), compared to an estimate of 0.24 obtained with the bias-corrected matching estimator.

Third, we account for possible changes in herd composition. All results presented so far rely on total herd size, treating animals of different species as equal. Yet, the recovery of livestock losses after the dzud is also influenced by natural reproduction rates, which vary across species and are highest for sheep and goats. There is no evidence that treated herders had a higher share of small animals in their herd, which would have explained their faster recovery: the share of sheep and goats in the herd in 2009, 2011, 2012, and 2014 is not statistically different between treated and control households. In 2013, treated herders even had a slightly lower percentage of sheep and goats. Table 9 displays estimates of the main specification using the bias-corrected matching estimator in which now all livestock holdings are transformed into horse units (called bod units in Mongolian), the conversion rate commonly used in Mongolia ${ }^{19}$ Again, results support our main findings: even when accounting for pre-shock and post-shock herd composition, receiving IBLI indemnity payments helped households recover from dzud losses.

Fourth, we explore the robustness of the retrospective livestock data. Recall that all results presented so far are based on information on pre-shock livestock holdings and livestock losses caused by the dzud recorded in the first panel wave. Table 10 , panel A shows results when we instead employ retrospective livestock data recorded in the third panel wave. Panel B shows estimates obtained when using retrospective information only if reported by the head of household (in either the first or third panel wave). All

\footnotetext{
${ }^{19}$ One bod unit is equivalent to one horse, one cow, 0.67 camels, six sheep, or eight goats.
} 
main results hold when using these alternative retrospectively recorded measures. This test illustrates the reliability of the retrospectively recorded information on past livestock holdings.

Lastly, we test whether treatment influenced households' livestock holdings immediately after the dzud (and before indemnity payments were paid), calculated as the difference between livestock holdings in 2009 and reported livestock losses due to dzud. If the estimated effects of treatment had a significant effect on this outcome, this would point toward unobservable factors at play that influence households' shock exposure and that we do not capture well with observed covariates. In line with expectations, results displayed in Table 11 from the bias-corrected matching, IPWRA, and AIPW estimators show that IBLI indemnity payments do not have a significant effect on livestock holdings immediately after the dzud.

\subsection{Unravelling the channels}

Lastly, we explore through what channels IBLI indemnity payments may have helped treated households recover faster. Recall that sample households that had purchased IBLI in 2009 received on average indemnity payments of 268,000 MNT (about 201 US\$) in 2010. Although underreporting seems very likely, this amount is not impressively large. For instance, this amount would have bought nine female goats, seven female sheep, one female horse, one cow, or one female camel at prices prevailing in Uvs province in 2010 (NSO 2011). It represents merely 7 percent of the yearly cash income from herding that households earned in 2012, when climatic conditions were particularly favorable for livestock activities. However, when asked to assess how helpful the indemnity payments were, most treated households in our sample were very satisfied. Of the 59 sample households that had purchased IBLI in 2009, 44 households (75 percent) indicated that they found the indemnity payments helpful to manage the consequences of the dzud, compared to 14 households (24 percent) indicating that they found the indemnity payments either too small or coming too late. In fact, the majority of households that received IBLI indemnity payments in 2010 continued purchasing IBLI in the post-dzud period: Of the 59 treated households, 37, 37 , and 14 households purchased IBLI again in 2012, 2013, and 2014, respectively.

Descriptive statistics indicate that treated sample households used IBLI indemnity payments mostly to cover household expenses. A large share of treated sample households - 43 households (73 percent) used the indemnity payments to buy food and other household necessities. Eight households (14 percent) used the indemnity payments to cover education and health expenses. Only 13 households (22 percent) reported using the indemnity payments for investments in livestock activities, such as buying livestock fodder and improving shelters. Surprisingly, none of the treated households reported using the indemnity payments to restock the herd. Interestingly, nine households (15 percent) used the indemnity payments to pay back a loan.

The faster asset recovery of insured households also appears to be a result of different shock coping strategies applied. Table 12 presents results from the bias-corrected matching estimator on the effect of treatment on the usage of five different shock coping strategies. Treated households were significantly less likely forced to sell livestock during or after dzud (when prices were low) compared to non-treated households. Treated households were also less likely to move animals in the midst of the dzud winter, a common informal coping strategy. Furthermore, treated households were significantly more likely to borrow money during the dzud. The magnitude of this effect is very large. Through purchasing IBLI, insured herders became customers of local commercial banks. These banks also offered credits at discounted 
interest rates to IBLI customers with the value of a household's livestock holdings as documented on the IBLI policy serving as collateral. Thus, this evidence suggests that IBLI indemnity payments helped treated households to relieve credit constraints during dzud and to smooth their productive assets.

Complementary qualitative in-depth interviews with a small sub-sample of herding households, local governors and insurance agents confirm this interpretation ${ }^{20}$ Several herders pointed out that it was not just livestock losses during the dzud months, but also the slaughtering of animals for meat consumption that made a difference for herd growth after the dzud.

Authors: What are the factors that helped you recover from the dzud so fast?

Herder: I think our hard work accounts for the most part. By preparing winter fodder very well, we made sure that as many livestock as possible survived the winter.

Authors: So you did not purchase any livestock? Received no aid?

Herder: No, nothing at all. Having only one child, we consumed less than other households, which mainly accounts for our fast recovery.

Another herder stressed how cash inflows can help herders avoid selling animals:

Herder: Money is the most helpful thing after dzud. This money can help us to buy primary consumption goods.

Other herders would rather use cash inflows to restock the herd with new animals:

Authors: If you had gotten some cash after the dzud, would it have helped you to recover?

Herder: Yes. To a certain extent, we could have invested in purchasing female livestock from within the region to nurture faster growth.

It appears that herders have a preference to purchase new livestock in spring when prices are low.

Authors: When is it most ideal to buy livestock after dzud?

Herder: Generally, in spring, in May.

Authors: So shortly after dzud. Aren't the animals then very weak?

Herder: Livestock are cheaper when they are thin.

Authors: Do you buy the thinner ones to strengthen them?

Herder: Exactly. We buy livestock thin and strengthen them until autumn.

Other herders stated they prefer purchasing livestock in spring as this would allow the new livestock to adapt to new pastures before the winter starts. Thus, it appears as if the timing of IBLI indemnity payments (starting in August) was less suited to restock the herd in 2010. Rather, treated households may have used a credit to purchase livestock during or shortly after the dzud and repaid the loan with the IBLI indemnity payments.

To conclude, treated households appear to have benefited from liquidity obtained from both IBLI indemnity payments and from relieved credit constraints. It seems that IBLI helped treated households recover faster by allowing them to avoid slaughtering and selling animals to pay for household expenses, as well as by purchasing livestock to restock their herds.

\footnotetext{
${ }^{20}$ We interviewed ten herders (none of whom had purchased IBLI in 2009), five sub-district governors, one agricultural officer, three IBLI project officers, the manager of a private insurance company selling IBLI, and three insurance agents in western Mongolia in June 2014. The aim of the qualitative interviews was to understand better factors contributing to herders' post-shock recovery and the role of IBLI therein. All interviews were recorded, transcribed and then translated into English.
} 


\section{Conclusion}

Index insurance is praised as a powerful tool that supports smallholder farmers and herders in developing countries in managing weather risk. Yet, there is scant empirical evidence to date on the actual benefits of index insurance for agricultural households. Our study is among the first that empirically investigates the ex post impacts of indemnity payments from index insurance after a shock occurs. Our focus is on the Index-Based Livestock Insurance in Mongolia, which is a fully commercial product available at the national level since 2012. We analyze the effect of IBLI indemnity payments after a once-in-50-year winter disaster struck Mongolia in 2009/10. This event caused the worst livestock losses ever recorded in a single winter. Our analysis tests if IBLI indemnity payments helped insured herders to recover their herd size faster than non-insured herders. The database for our analysis is three waves of a household panel survey implemented in western Mongolia. One particular feature of the survey is that it asks households retrospectively about the purchase of IBLI before the winter disaster, their shock exposure, coping strategies applied as well as livestock holdings at different points in time. Given the lack of randomization in the implementation of the IBLI scheme, we employ the bias-corrected matching estimator to account for selection into purchasing IBLI in 2009, just before the disaster occurred. Our empirical strategy exploits the phasing-in of the IBLI scheme. This helps us to exclude the possibility of spillover effects and minimize the potential bias stemming from unobserved characteristics influencing both the selection into treatment and outcome variables.

Pastoralist households purchasing IBLI before the shock and receiving indemnity payments in 2010 recovered faster from shock-induced asset losses than comparable non-insured households. We find a significant, positive and economically large effect of IBLI indemnity payments on herd size both one and two years after the shock. In the medium term - three and four years after the shock - the effect is still visible but narrowing. These findings, obtained with the bias-corrected matching estimator, hold both when using livestock holdings in the post-shock period and cumulative growth rates in livestock. Results are also robust to varying the number of matches per observation, the choice of covariates, and to the usage of alternative double robust estimators. Also, we can exclude the possibility that the effect is driven by a change in herd composition toward smaller animals with higher reproduction rates among treated households.

An analysis of shock coping strategies as well as complementary qualitative interviews conducted in the field suggest that herders benefit from IBLI indemnity payments through two channels: On the one hand, indemnity payments are used to cover expenses for food, education, and health. Herders can thus avoid selling and slaughtering animals and smooth their productive asset base. On the other hand, IBLI appears to have relieved households from credit constraints. Insured households were more likely to take credit during the disaster, which may have been used to purchase new livestock. Access to credit appears to be a positive side-effect of IBLI on rural financial markets.

Our analysis is restricted to some limitations and shortcomings. First, our analysis rests on the - untestable assumption that we capture the voluntary purchase decision of IBLI with observed covariates, with no unobservable factors remaining. Second, all treated households in our sample stayed in the herding economy in the aftermath of the shock. In contrast, about 10 percent of the non-insured sample households dropped out of the herding economy after 2009 and did no longer own any livestock at the time of the survey (and were therefore excluded from our regression sample). Hence, it is not possible to draw conclusions on whether IBLI helped households to avoid dropping out of the herding economy. Our results 
might be considered as a conservative estimate of the positive effect of IBLI payments on households' disaster recovery. Finally, the small number of treated sample households does not allow for a more detailed analysis of heterogeneous treatment effects. 


\section{References}

Abadie, A., D. Drukker, J. L. Herr, and G. W. Imbens (2004). Implementing matching estimators for average treatment effects in Stata. Stata Journal 4, 290-311.

Abadie, A. and G. Imbens (2002). Simple and bias-corrected matching estimators for average treatment effects. NBER Working Paper 283, National Bureau of Economic Research, Cambridge, MA.

Abadie, A. and G. W. Imbens (2006). Large sample properties of matching estimators for average treatment effects. Econometrica 74(1), 235-267.

Abadie, A. and G. W. Imbens (2011). Bias-corrected matching estimators for average treatment effects. Journal of Business 83 Economic Statistics 29(1), 1-11.

Barnett, B. J., C. B. Barrett, and J. R. Skees (2008). Poverty traps and index-based risk transfer products. World Development 36(10), 1766-1785.

Barnett, B. J. and O. Mahul (2007). Weather index insurance for agriculture and rural areas in lowerincome countries. American Journal of Agricultural Economics 89(5), 1241-1247.

Batima, P. (2006). Climate change vulnerability and adaptation in the livestock sector of Mongolia. Final Report Submitted to Assessments of Impacts and Adaptations to Climate Change (AIACC), International START Secretariat, Washington DC.

Binswanger-Mkhize, H. P. (2012). Is there too much hype about index-based agricultural insurance? The Journal of Development Studies 48(2), 187-200.

Carter, M. (2009). Innovations in insuring the poor: Intelligent design of index insurance for smallholder farmers and pastoralists. 2020 Vision Focus Brief 17(6), IFPRI, Washington D.C.

Carter, M., A. de Janvry, E. Sadoulet, and A. Sarris (2014). Index-based weather insurance for developing countries: A review of evidence and a set of propositions for up-scaling. Development Policies Working Paper 111, FERDI, Clermont-Ferrand.

Clarke, D. J. et al. (2011). A theory of rational demand for index insurance. Discussion Paper 572, Department of Economics, University of Oxford.

Cole, S., D. Stein, and J. Tobacman (2014). Dynamics of demand for index insurance: Evidence from a long-run field experiment. The American Economic Review 104(5), 284-290.

Cole, S. A., X. Giné, and J. I. Vickery (2013). How does risk management influence production decisions? Evidence from a field experiment. World Bank Policy Research Working Paper 6546, World Bank, Washington D.C.

De Angelis, K. (2013). Index-based livestock insurance: The case of Mongolia. Inside Stories on climate compatible development, CDKN, London.

Elabed, G. and M. R. Carter (2014). Ex-ante impacts of agricultural insurance: Evidence from a field experiment in Mali. Unpublished.

Feibel, B. J. (2002). Calculating investment returns. In F. J. Fabozzi (Ed.), Handbook of Finance, pp. 35-66. Wiley Online Library. 
Fernández-Giménez, M. E., B. Batkhishig, B. Batbuyan, and T. Ulambayar (2015). Lessons from the dzud: Community-based rangeland management increases the adaptive capacity of Mongolian herders to winter disasters. World Development 68, 48-65.

Gaurav, S., S. Cole, and J. Tobacman (2011). Marketing complex financial products in emerging markets: Evidence from rainfall insurance in India. Journal of Marketing Research 48, 150-162.

Giné, X., R. Townsend, and J. Vickery (2008). Patterns of rainfall insurance participation in rural India. The World Bank Economic Review 22(3), 539-566.

Giné, X. and D. Yang (2009). Insurance, credit, and technology adoption: Field experimental evidencefrom Malawi. Journal of Development Economics 89(1), 1-11.

Goodland, A., D. Sheehy, and T. Shine (2009). Mongolia: Livestock sector study, volumne I - Synthesis report. World Bank, Washington D.C.

Greatrex, H., J. Hansen, S. Garvin, R. Diro, M. Le Guen, S. Blakeley, K. Rao, and D. Osgood (2015). Scaling up index insurance for smallholder farmers: Recent evidence and insights. CCAFS Report, CGIAR, Copenhagen.

Groppo, V. and K. Schindler (2014). Extreme weather events and child height: Evidence from Mongolia. DIW Berlin Discussion Paper 1403, DIW Berlin.

Guo, S. and M. W. Fraser (2010). Propensity score analysis: Statistical methods and applications. Thousand Oaks: SAGE Publications.

Hardeweg, B., L. Menkhoff, and H. Waibel (2013). Experimentally validated survey evidence on individual risk attitudes in rural Thailand. Economic Development and Cultural Change 61(4), 859-888.

Hartell, J. (2011). Developing an impact assessment strategy for the Mongolian Index-Based Livestock Insurance pilot. GlobalAgRisk, Lexington.

Hill, R. V. and A. Viceisza (2012). A field experiment on the impact of weather shocks and insurance on risky investment. Experimental Economics 15(2), 341-371.

IBLI PIU (2012). Index-Based Livestock Insurance (IBLI) project implementation report 2005-2012. IBLI Project Implementation Unit (PIU), Ulaanbaatar.

IFRC and MRCS (2010). Mongolia information bulletin no 1: cold waves. International Federation of Red Cross and Red Crescent Societies (IFRC) and Mongolian Red Cross Society (MRCS), Ulanbaatar.

Imbens, G. W. (2000). The role of the propensity score in estimating dose-response functions. Biometrika 87(3), 706-710.

Janzen, S. A. and M. R. Carter (2013). After the drought: The impact of microinsurance on consumption smoothing and asset protection. NBER Working Paper 19702, National Bureau of Economic Research, Cambridge, MA.

Karlan, D., R. Osei, and I. Osei (2014). Agricultural decisions after relaxing credit and risk constraints. Quarterly Journal of Economics 129(2), 597-652.

Law of Mongolia (2014). Index-based livestock insurance law. State Information Publication Booklet 26/839, Ulanbaatar. 
Mahul, O. and J. Skees (2007). Managing agricultural risk at the country level: The case of Index-Based Livestock Insurance in Mongolia. World Bank Policy Research Paper 4325, World Bank, Washington D.C.

Miranda, M. J. and K. Farrin (2012). Index insurance for developing countries. Applied Economic Perspectives and Policy $34(3), 391-427$.

Mobarak, A. M. and M. Rosenzweig (2012). Selling formal insurance to the informally insured. Working Paper, Number 97, Department of Economics, Yale University.

Mobarak, A. M. and M. Rosenzweig (2014). Risk, insurance and wages in general equilibrium. NBER Working Paper 19811, National Bureau of Economic Research, Cambridge, MA.

Mobarak, A. M. and M. R. Rosenzweig (2013). Informal risk sharing, index insurance, and risk taking in developing countries. The American Economic Review 103(3), 375-380.

Murphy, D. J. (2011). Going on otor: disaster, mobility, and the political ecology of vulnerability in Uguumur, Mongolia. Ph. D. thesis, Department of Anthropology, University of Kentucky.

Nielsen, T., A. Keil, and M. Zeller (2013). Assessing farmers' risk preferences and their determinants in a marginal upland area of Vietnam: A comparison of multiple elicitation techniques. Agricultural Economics $44(3), 255-273$.

NSO (2011). Statistical Yearbook 2010. National Statistical Office Mongolia, Ulaanbaatar.

NSO (2013). Statistical Yearbook 2012. National Statistical Office Mongolia, Ulaanbaatar.

Skees, J. and A. Enkh-Amgalan (2002). Examining the feasibility of livestock insurance in Mongolia. World Bank Policy Research Paper 2886, World Bank, Washington D.C.

Skees, J. R. and B. J. Barnett (2006). Enhancing microfinance using index-based risk-transfer products. Agricultural Finance Review 66(2), 235-250.

Sternberg, T. (2010). Unravelling Mongolia's extreme winter disaster of 2010. Nomadic Peoples 14(1), $72-86$.

UNDP and NEMA (2010). Dzud National Report 2009-2010. United Nations Development Program (UNDP) and National Emergency Management Agency (NEMA), Ulaanbaatar.

Wooldridge, J. M. (2007). Inverse probability weighted estimation for general missing data problems. Journal of Econometrics 141(2), 1281-1301.

Wooldridge, J. M. (2010). Econometric analysis of cross section and panel data. MIT Press.

World Bank (2013). Implementing agriculture for development: World Bank Group Agriculture Action Plan (2013-2015). World Bank, Washington D.C. 


\section{Figures and Tables}

Figure 1: Livestock development in western Mongolia, 1970-2014

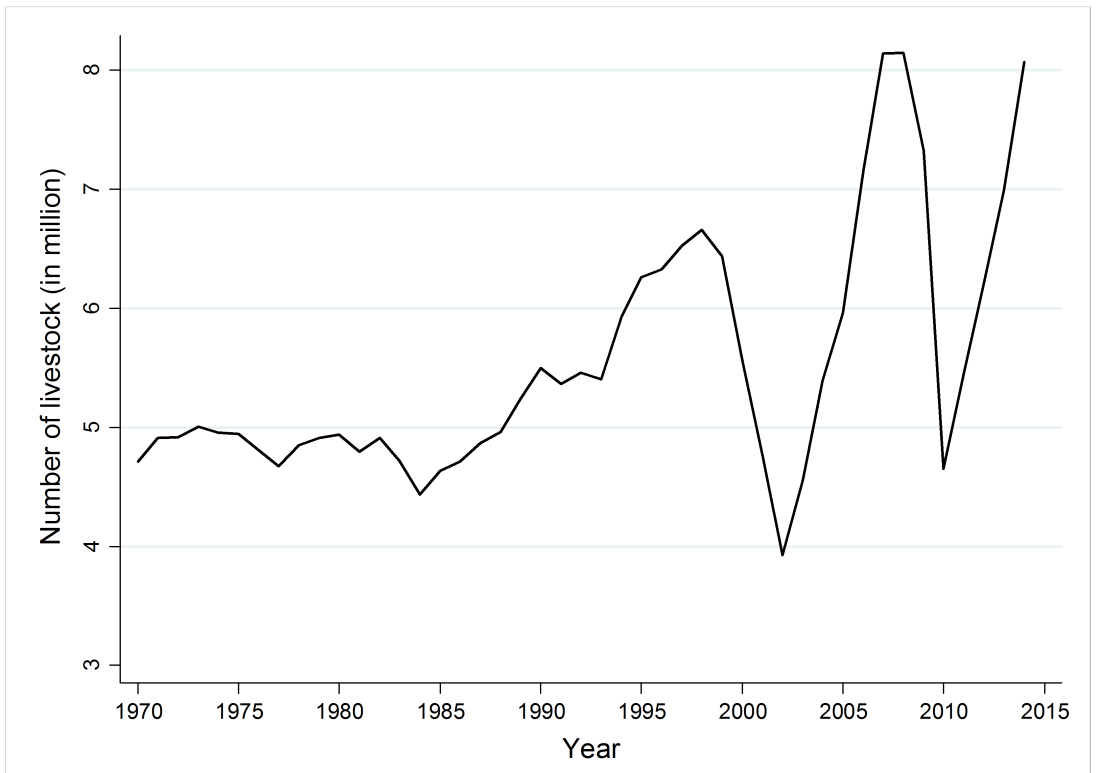

Note: Livestock include camel, cattle, horse, sheep, and goat. Data shown for the provinces Uvs, Zavkhan, and Govi-Altai. Source: Author's calculations based on the Mongolia Livestock Census. 
Figure 2: Map of Mongolia, showing the year in which IBLI was introduced in each province

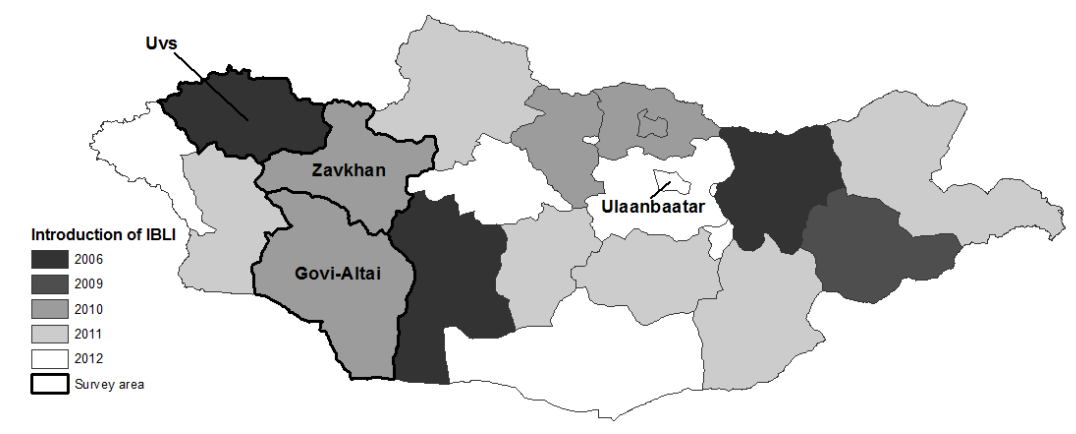

Notes: The three provinces where the household survey was implemented are bold-rimmed. Adapted from PIU (2012). 
Figure 3: Overlap in covariates across treated and control households

(a) Minimal set of covariates

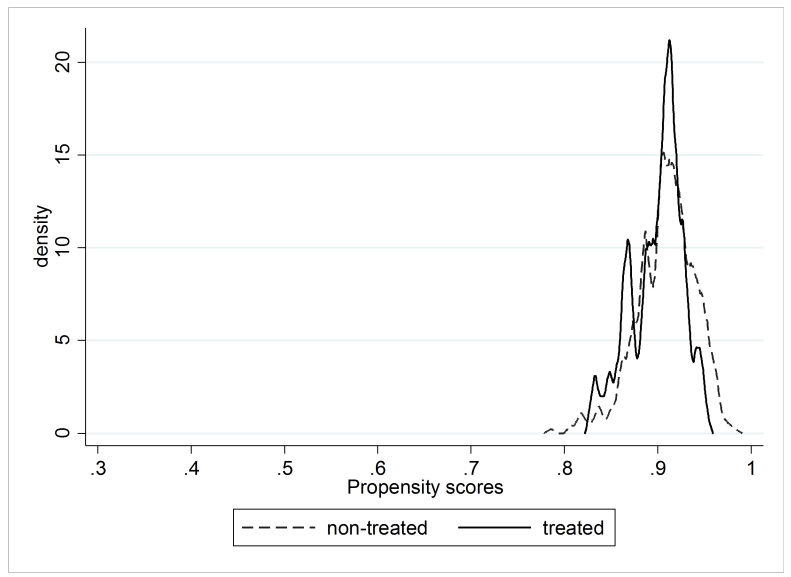

(b) Core set of covariates

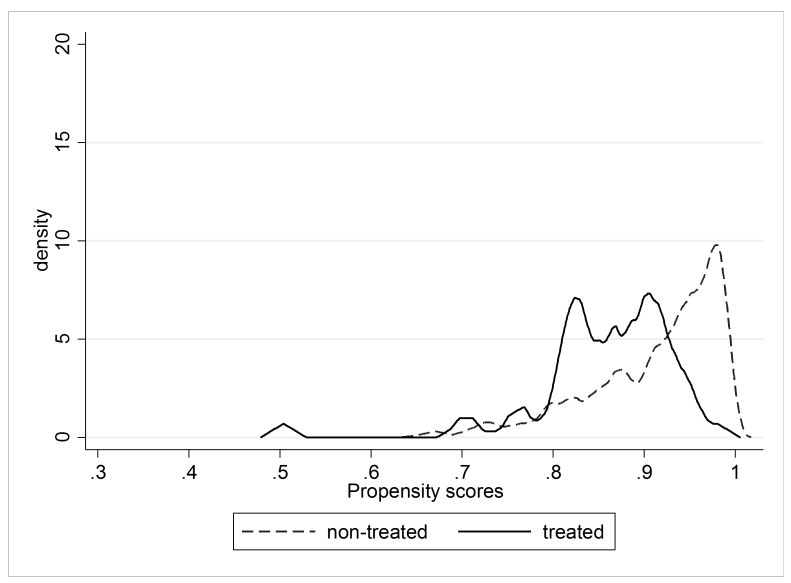

(c) Maximal set of covariates

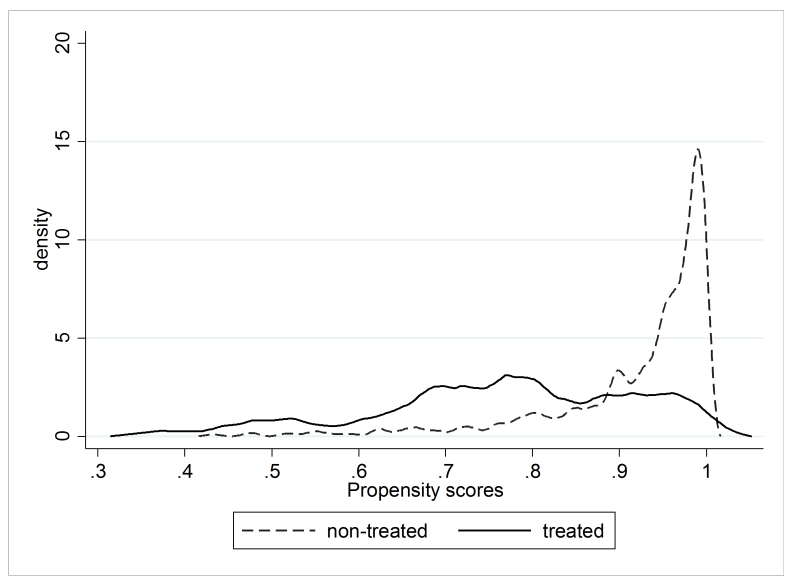

Notes: The figures show the overlap in the propensity scores of covariates of treated and non-treated households. See Table 5 for details on the definition of the set of covariates. The propensity scores are estimated using the augmentedinverse probability weighting estimation with number of livestock (log) in 2012 as outcome variable. Source: Coping with Shocks in Mongolia Household Panel Survey and Mongolia Livestock Census. 
Figure 4: Map of the survey area, showing livestock mortality in 2010 per sub-district

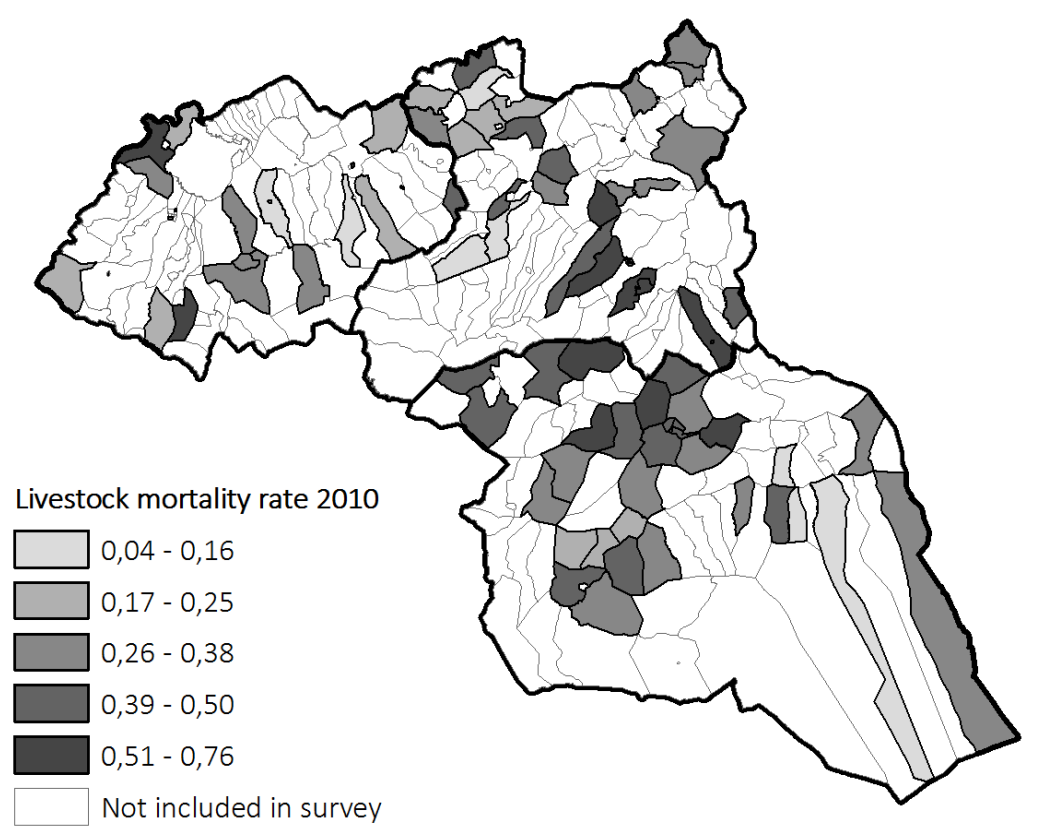

Note: The map shows the three provinces of Uvs, Zavkhan, and Govi-Altai where the household survey was implemented. Source: Mongolia Livestock Census. 


\begin{tabular}{|c|c|c|c|c|c|}
\hline & mean & sd & $\min$ & $\max$ & observations \\
\hline \multicolumn{6}{|l|}{ outcome } \\
\hline number of livestock 2011 & 197.05 & 180.37 & 2 & 1,565 & 642 \\
\hline number of livestock 2012 & 199.80 & 183.23 & 3 & 1,613 & 642 \\
\hline number of livestock 2013 & 242.59 & 220.62 & 5 & 1,609 & 608 \\
\hline number of livestock 2014 & 278.13 & 255.04 & 4 & 1,867 & 581 \\
\hline cumulated livestock growth rate, 2009-2011 & -0.21 & 0.28 & -0.88 & 0.75 & 642 \\
\hline cumulated livestock growth rate, 2009-2012 & -0.15 & 0.20 & -0.70 & 0.58 & 642 \\
\hline cumulated livestock growth rate, 2009-2013 & -0.09 & 0.17 & -0.69 & 0.48 & 608 \\
\hline cumulated livestock growth rate, 2009-2014 & -0.05 & 0.15 & -0.47 & 0.37 & 581 \\
\hline coping strategy: sold livestock & 0.17 & 0.37 & 0 & 1 & 642 \\
\hline coping strategy: moved livestock during dzud & 0.36 & 0.48 & 0 & 1 & 642 \\
\hline coping strategy: borrowed money & 0.32 & 0.47 & 0 & 1 & 642 \\
\hline coping strategy: organized add. labor for herding & 0.21 & 0.41 & 0 & 1 & 642 \\
\hline coping strategy: built shelter or fences for livestock & 0.09 & 0.29 & 0 & 1 & 642 \\
\hline \multicolumn{6}{|l|}{ treatment } \\
\hline purchased IBLI in 2009 & 0.09 & 0.29 & 0 & 1 & 642 \\
\hline $\begin{array}{l}\text { value of IBLI payouts household received in } 2010 \\
\text { (in thousand MNT) }\end{array}$ & 268.29 & 245.92 & 38 & 1,300 & 58 \\
\hline \multicolumn{6}{|l|}{ household head controls } \\
\hline no education & 0.13 & 0.34 & 0 & 1 & 642 \\
\hline primary education & 0.58 & 0.49 & 0 & 1 & 642 \\
\hline secondary education & 0.29 & 0.45 & 0 & 1 & 642 \\
\hline age & 44.66 & 12.39 & 19 & 87 & 642 \\
\hline risk preference $(0=$ risk averse, $10=$ risk loving $)$ & 4.24 & 3.39 & 0 & 10 & 642 \\
\hline knows the sub-district governor very well & 0.50 & 0.50 & 0 & 1 & 642 \\
\hline \multicolumn{6}{|l|}{ household controls } \\
\hline number of livestock in 2009 & 312.84 & 236.09 & 10 & 1,800 & 642 \\
\hline number of livestock lost due to $2009 / 2010$ dzud & 142.15 & 135.95 & 1 & 950 & 642 \\
\hline percent of breeding stock & 0.37 & 0.09 & 0 & 0.90 & 642 \\
\hline $\begin{array}{l}\text { relative subjective economic wellbeing in } 2009 \\
(0=\text { among the poorest, } 10=\text { among the richest })\end{array}$ & 5.77 & 1.50 & 1 & 10 & 642 \\
\hline number of economically active members & 2.08 & 1.05 & 0 & 7 & 642 \\
\hline location is rural & 0.62 & 0.48 & 0 & 1 & 642 \\
\hline \multicolumn{6}{|l|}{ sub-district controls } \\
\hline livestock mortality in 2010 & 0.37 & 0.14 & 0.05 & 0.76 & 642 \\
\hline \multicolumn{6}{|l|}{ district controls } \\
\hline ecological zone is mountain steppe & 0.26 & 0.44 & 0 & 1 & 642 \\
\hline ecological zone is forest steppe & 0.13 & 0.34 & 0 & 1 & 642 \\
\hline ecological zone is grass steppe & 0.29 & 0.45 & 0 & 1 & 642 \\
\hline ecological zone is desert steppe/desert & 0.32 & 0.47 & 0 & 1 & 642 \\
\hline cellphone coverage $(1=$ in few areas; $4=$ in all areas $)$ & 2.74 & 0.86 & 1 & 4 & 642 \\
\hline number of transport options to provincial center & 1.51 & 0.86 & 0 & 3 & 642 \\
\hline
\end{tabular}

Source: Coping with Shocks in Mongolia Household Panel Survey and Mongolia Livestock Census. 
Table 2: Determinants of purchasing IBLI in 2009 (probit)

\begin{tabular}{|c|c|c|}
\hline outcome variable & $\begin{array}{c}\text { purchased IBLI } \\
(1)\end{array}$ & $\begin{array}{c}\text { purchased IBLI } \\
(2)\end{array}$ \\
\hline \multicolumn{3}{|l|}{ household head controls } \\
\hline \multirow[t]{2}{*}{ primary education } & -0.029 & 0.101 \\
\hline & $(0.93)$ & $(0.79)$ \\
\hline \multirow[t]{2}{*}{ secondary education } & 0.203 & 0.479 \\
\hline & $(0.55)$ & $(0.26)$ \\
\hline \multirow[t]{2}{*}{ age } & 0.006 & 0.009 \\
\hline & $(0.43)$ & $(0.36)$ \\
\hline \multirow[t]{2}{*}{ risk preference } & 0.064 & 0.064 \\
\hline & $(0.12)$ & $(0.20)$ \\
\hline \multicolumn{3}{|l|}{ household controls } \\
\hline \multirow[t]{2}{*}{ number of livestock in 2009 (logs) } & $0.330^{* *}$ & $0.608^{* * *}$ \\
\hline & $(0.03)$ & $(0.00)$ \\
\hline \multirow[t]{2}{*}{ relative subjective economic wellbeing in 2009} & 0.039 & 0.074 \\
\hline & $(0.55)$ & $(0.34)$ \\
\hline \multirow[t]{2}{*}{ location is rural } & -0.133 & 0.016 \\
\hline & $(0.61)$ & $(0.95)$ \\
\hline \multicolumn{3}{|l|}{ district controls } \\
\hline \multirow[t]{2}{*}{ ecological zone is mountain steppe } & -0.165 & \\
\hline & $(0.51)$ & \\
\hline \multirow[t]{2}{*}{ ecological zone is forest steppe } & $0.737^{* *}$ & \\
\hline & $(0.04)$ & \\
\hline \multirow[t]{2}{*}{ ecological zone is grass steppe } & 0.323 & \\
\hline & $(0.22)$ & \\
\hline \multirow[t]{2}{*}{ cellphone coverage } & -0.162 & \\
\hline & $(0.11)$ & \\
\hline \multirow[t]{2}{*}{ number of transportation options to provincial center } & -0.043 & \\
\hline & $(0.79)$ & \\
\hline \multirow[t]{2}{*}{ constant } & $-2.734^{* * *}$ & $-3.597 * * *$ \\
\hline & $(0.00)$ & $(0.00)$ \\
\hline district fixed effects & no & yes \\
\hline observations & 263 & 188 \\
\hline
\end{tabular}

Notes: P-values are reported in brackets with ${ }^{*}$ significant at $10 \%$; ${ }^{* *}$ significant at $5 \%$; ${ }^{* * *}$ significant at $1 \%$. The sample comprises all herders in the province of Uvs where IBLI was available in 2009. Source: Coping with Shocks in Mongolia Household Panel Survey and Mongolia Livestock Census. 
Table 3: Determinants of household livestock losses due to the 2009/10 dzud (OLS)

\begin{tabular}{|c|c|}
\hline outcome variable & $\begin{array}{c}\text { number of livestock lost } \\
\text { due to } 2009 / 10 \text { dzud (in logs) }\end{array}$ \\
\hline purchased IBLI in 2009 & $\begin{array}{l}-0.082 \\
(0.91)\end{array}$ \\
\hline $\begin{array}{l}\text { household head controls } \\
\text { primary education }\end{array}$ & $\begin{array}{r}-0.032 \\
(0.69)\end{array}$ \\
\hline secondary education & $\begin{array}{r}-0.096 \\
(0.30)\end{array}$ \\
\hline age & $\begin{array}{l}0.002 \\
(0.36)\end{array}$ \\
\hline risk preference & $\begin{array}{c}-0.021^{* * *} \\
(0.00)\end{array}$ \\
\hline $\begin{array}{l}\text { household controls } \\
\text { number of livestock in } 2009 \text { (in logs) }\end{array}$ & $\begin{array}{l}0.902^{* * *} \\
\quad(0.00)\end{array}$ \\
\hline relative subjective economic wellbeing in 2009 & $\begin{array}{l}0.007 \\
(0.73)\end{array}$ \\
\hline location is rural & $\begin{array}{l}-0.171 \\
(0.10)\end{array}$ \\
\hline $\begin{array}{l}\text { sub-district controls } \\
\text { livestock mortality in } 2010\end{array}$ & $\begin{array}{r}0.458 \\
(0.21)\end{array}$ \\
\hline constant & $\begin{array}{l}-0.345 \\
(0.45)\end{array}$ \\
\hline $\begin{array}{l}\text { district fixed effects } \\
R^{2} \\
\text { observations }\end{array}$ & $\begin{array}{c}\text { yes } \\
0.587 \\
642\end{array}$ \\
\hline
\end{tabular}

Notes: P-values are reported in brackets with ${ }^{*}$ significant at $10 \% ;{ }^{* *}$ significant at $5 \% ;{ }^{* *}$ significant at $1 \%$. Source: Coping with Shocks in Mongolia Household Panel Survey and Mongolia Livestock Census. 
Table 4: Comparison of characteristics across treated and control households

\begin{tabular}{|c|c|c|c|}
\hline & \multicolumn{2}{|c|}{ means } & \multirow{2}{*}{$\begin{array}{c}\text { p-values } \\
\\
\text { (3) }\end{array}$} \\
\hline & $\begin{array}{c}\text { treated } \\
\text { households } \\
\text { (purchased IBLI } \\
\text { in 2009) } \\
\mathrm{N}=59 \\
(1)\end{array}$ & $\begin{array}{c}\text { non-treated } \\
\text { households } \\
\text { (did not purchase } \\
\text { IBLI in 2009) } \\
\mathrm{N}=583 \\
(2)\end{array}$ & \\
\hline \multicolumn{4}{|l|}{ household head controls } \\
\hline no education & 0.10 & 0.13 & 0.51 \\
\hline primary education & 0.56 & 0.58 & 0.72 \\
\hline secondary education & 0.34 & 0.28 & 0.38 \\
\hline age & 45.08 & 44.61 & 0.78 \\
\hline risk preference & 2.59 & 4.41 & $0.00^{* * *}$ \\
\hline knows the sub-district governor very well & 0.20 & 0.53 & $0.00^{* * *}$ \\
\hline \multicolumn{4}{|l|}{ household controls } \\
\hline number of livestock in 2009 & 349.15 & 309.17 & 0.22 \\
\hline number of livestock lost due to $2009 / 2010$ dzud & 130.07 & 143.38 & 0.47 \\
\hline percent of breeding stock in 2012 & 0.38 & 0.37 & 0.49 \\
\hline relative subjective economic wellbeing in 2009 & 6.10 & 5.74 & $0.08^{*}$ \\
\hline number of economically active members & 2.56 & 2.03 & $0.00^{* * *}$ \\
\hline location is rural & 0.76 & 0.61 & $0.02^{* *}$ \\
\hline \multicolumn{4}{|l|}{ sub-district controls } \\
\hline livestock mortality in 2010 & 0.31 & 0.37 & $0.00^{* * *}$ \\
\hline \multicolumn{4}{|l|}{ district controls } \\
\hline mountain steppe & 0.20 & 0.26 & 0.32 \\
\hline forest steppe & 0.15 & 0.13 & 0.58 \\
\hline grass steppe & 0.27 & 0.29 & 0.78 \\
\hline desert steppe/desert & 0.37 & 0.32 & 0.43 \\
\hline cellphone coverage & 2.58 & 2.75 & 0.13 \\
\hline number of transport options to provincial center & 1.41 & 1.52 & 0.34 \\
\hline
\end{tabular}

Notes: Colum 3 shows p-values on tests on differences in means between treated and non-treated households. T-tests are used for continuous variables, chi-square tests for non-continuous variables with * significant at $10 \%$; $* *$ significant at 5\%; *** significant at 1\%. Source: Coping with Shocks in Mongolia Household Panel Survey and Mongolia Livestock Census. 
Table 5: Impact of IBLI indemnity payments on recovery from the 2009/10 dzud (bias-corrected matching estimator, baseline results)

\begin{tabular}{|c|c|c|c|c|c|c|c|c|}
\hline \multirow[t]{2}{*}{ outcome variables } & \multicolumn{4}{|c|}{ number of livestock (in logs) } & \multicolumn{4}{|c|}{ cum. livestock growth rate } \\
\hline & $\begin{array}{l}2011 \\
(1)\end{array}$ & $\begin{array}{r}2012 \\
(2)\end{array}$ & $\begin{array}{r}2013 \\
(3) \\
\end{array}$ & $\begin{array}{r}2014 \\
(4) \\
\end{array}$ & $\begin{array}{c}2009- \\
2011 \\
(5)\end{array}$ & $\begin{array}{c}2009- \\
2012 \\
(6)\end{array}$ & $\begin{array}{c}2009- \\
2013 \\
(7)\end{array}$ & $\begin{array}{c}2009- \\
2014 \\
(8) \\
\end{array}$ \\
\hline $\begin{array}{l}\text { panel A: minimal set of covariates } \\
\text { purchased IBLI in } 2009\end{array}$ & $\begin{array}{c}0.165^{* *} \\
(0.02)\end{array}$ & $\begin{array}{c}0.197^{* *} \\
(0.01)\end{array}$ & $\begin{array}{l}0.121 \\
(0.20)\end{array}$ & $\begin{array}{l}0.091 \\
(0.34)\end{array}$ & $\begin{array}{l}0.032 \\
(0.20)\end{array}$ & $\begin{array}{c}0.040^{* *} \\
(0.04)\end{array}$ & $\begin{array}{l}0.021 \\
(0.30)\end{array}$ & $\begin{array}{l}0.012 \\
(0.49)\end{array}$ \\
\hline $\begin{array}{l}\text { panel B: core set of covariates } \\
\text { purchased IBLI in } 2009\end{array}$ & $\begin{array}{c}0.189^{* *} \\
(0.04)\end{array}$ & $\begin{array}{l}0.241^{* *} \\
(0.02)\end{array}$ & $\begin{array}{l}0.156 \\
(0.13)\end{array}$ & $\begin{array}{l}0.107 \\
(0.34)\end{array}$ & $\begin{array}{l}0.044 \\
(0.14)\end{array}$ & $\begin{array}{l}0.052^{* * *} \\
(0.00)\end{array}$ & $\begin{array}{c}0.029^{*} \\
(0.08)\end{array}$ & $\begin{array}{l}0.015 \\
(0.34)\end{array}$ \\
\hline $\begin{array}{l}\text { panel C: maximal set of covariates } \\
\text { purchased IBLI in } 2009\end{array}$ & $\begin{array}{l}0.149 \\
(0.15)\end{array}$ & $\begin{array}{c}0.223^{* *} \\
(0.04)\end{array}$ & $\begin{array}{l}0.096 \\
(0.39)\end{array}$ & $\begin{array}{l}0.071 \\
(0.54)\end{array}$ & $\begin{array}{l}0.030 \\
(0.39)\end{array}$ & $\begin{array}{c}0.048^{* *} \\
(0.04)\end{array}$ & $\begin{array}{l}0.017 \\
(0.38)\end{array}$ & $\begin{array}{l}0.008 \\
(0.63)\end{array}$ \\
\hline mean outcome of control households & 4.747 & 4.741 & 4.941 & 5.087 & -0.210 & -0.158 & -0.087 & -0.047 \\
\hline observations & 642 & 642 & 608 & 581 & 642 & 642 & 608 & 581 \\
\hline $\begin{array}{l}\text { Notes: Displayed is the estimated coefficient } \\
\text { of covariates includes number of livestock in } \\
\text { of covariates additionally includes head of h } \\
\text { economic wellbeing in } 2009 \text {, location of resid } \\
\text { coverage, transportation). In Panel C, the } \\
\text { percentage of breeding stock, and number of } \\
\text { is the geometric mean for outcomes expresse } \\
\text { P-values are reported in brackets with * sign } \\
\text { Mongolia Household Panel Survey and Mong }\end{array}$ & $\begin{array}{l}\text { of treatmer } \\
2009 \text {, numb } \\
\text { pusehold cor } \\
\text { ence), sub-c } \\
\text { aximal set } \\
\text { economical } \\
\text { d in logs an } \\
\text { ificant at } 1 \\
\text { rolia Livestc }\end{array}$ & $\begin{array}{l}\text { er of livestc } \\
\text { trols (age, } \\
\text { istrict cont } \\
\text { f covariate } \\
\text { y active ho } \\
\text { d the arithr } \\
\%{ }^{* *} \text { signi } \\
\text { ck Census. }\end{array}$ & $\begin{array}{l}\text { ck lost du } \\
\text { ducation, } \\
\text { ols (livest } \\
\text { addition } \\
\text { isehold } m \\
\text { etic mea } \\
\text { icant at } 5\end{array}$ & $\begin{array}{l}\text { ring dzud } \\
\text { risk prefe } \\
\text { ock mort } \\
\text { lly includ } \\
\text { embers. } \\
\text { otherwis } \\
\% \text {; }{ }^{* * *} \mathrm{si}\end{array}$ & $\begin{array}{l}\text { and ecolo } \\
\text { rence), ho } \\
\text { lity in } 201 \\
\text { es the rela } \\
\text { "he mean c } \\
\text { e. Four mi } \\
\text { nificant at }\end{array}$ & $\begin{array}{l}\text { tions. In } \mathrm{Pa} \\
\text { yical zone. } \mathrm{I} \\
\text { sehold contr } \\
\text { ), and distr } \\
\text { ionship to tl } \\
\text { utcome of co } \\
\text { tches are use } \\
1 \% \text {. Source: }\end{array}$ & $\begin{array}{l}\text { el A, the } \\
\text { Panel B } \\
\text { ls (relati } \\
\text { ct contro } \\
\text { e local gc } \\
\text { atrol hou } \\
\text { d for eve } \\
\text { Coping }\end{array}$ & $\begin{array}{l}\text { nimal set } \\
\text { core set } \\
\text { ubjective } \\
\text { ellphone } \\
\text { nor, } \\
\text { lds } \\
\text { bservation. } \\
\text { Shocks in }\end{array}$ \\
\hline
\end{tabular}


Table 6: Impact of doses of treatment on recovery from the 2009/10 dzud (OLS with propensity score weighting)

\begin{tabular}{lcc}
\hline \hline outcome variables & $\begin{array}{c}\text { number of livestock } \\
\text { in } 2012 \text { (in logs) }\end{array}$ & $\begin{array}{c}\text { cum. livestock } \\
\text { growth rate } \\
2009-2012 \\
(2)\end{array}$ \\
\hline received low indemnity payments in $2010(<90$ US $\$)$ & $(1)$ & $0.139^{* *}$ \\
received high indemnity payments in $2010(>90$ US $\$)$ & $0.167^{* *}$ & $(0.11)$ \\
& $(0.02)$ & 0.030 \\
mean outcome of control households & & $0.13)$ \\
core set of covariates & 4.741 & -0.158 \\
observations & yes & yes \\
\hline \hline
\end{tabular}

Notes: Displayed is the estimated coefficient of treatment (ATE) obtained from 2 separate weighted estimations with the core set of covariates included (see table 5 for details). The baseline category is not receiving indemnity payments. P-values are reported in brackets with ${ }^{*}$ significant at $10 \%$; ${ }^{* *}$ significant at $5 \%$; ${ }^{* *}$ significant at $1 \%$. Standard errors are clustered at the PSU level. Source: Coping with Shocks in Mongolia Household Panel Survey and Mongolia Livestock Census. 
Table 7: Robustness test: Results from bias-corrected matching estimator with varying number of matches per observation

\begin{tabular}{|c|c|c|c|c|c|c|c|c|}
\hline \multirow[t]{2}{*}{ outcome variables } & \multicolumn{4}{|c|}{ number of livestock (in logs) } & \multicolumn{4}{|c|}{ cum. livestock growth rate } \\
\hline & $\begin{array}{l}2011 \\
(1) \\
\end{array}$ & $\begin{array}{r}2012 \\
(2)\end{array}$ & $\begin{array}{r}2013 \\
(3) \\
\end{array}$ & $\begin{array}{r}2014 \\
(4) \\
\end{array}$ & $\begin{array}{c}2009- \\
2011 \\
(5)\end{array}$ & $\begin{array}{c}2009- \\
2012 \\
(6)\end{array}$ & $\begin{array}{c}2009- \\
2013 \\
(7) \\
\end{array}$ & $\begin{array}{c}2009- \\
2014 \\
(8) \\
\end{array}$ \\
\hline $\begin{array}{l}\text { panel A: two matches per observation } \\
\text { purchased IBLI in } 2009\end{array}$ & $\begin{array}{l}0.183^{*} \\
(0.06)\end{array}$ & $\begin{array}{c}0.230^{* *} \\
(0.03)\end{array}$ & $\begin{array}{l}0.161 \\
(0.12)\end{array}$ & $\begin{array}{l}0.077 \\
(0.50)\end{array}$ & $\begin{array}{l}0.042 \\
(0.15)\end{array}$ & $\begin{array}{c}0.049^{* *} \\
(0.02)\end{array}$ & $\begin{array}{r}0.030^{*} \\
(0.08)\end{array}$ & $\begin{array}{l}0.010 \\
(0.55)\end{array}$ \\
\hline $\begin{array}{l}\text { panel B: six matches per observation } \\
\text { purchased IBLI in } 2009\end{array}$ & $\begin{array}{c}0.202^{* *} \\
(0.04)\end{array}$ & $\begin{array}{c}0.253^{* *} \\
(0.01)\end{array}$ & $\begin{array}{l}0.166 \\
(0.11)\end{array}$ & $\begin{array}{l}0.124 \\
(0.27)\end{array}$ & $\begin{array}{l}0.049 \\
(0.10)\end{array}$ & $\begin{array}{l}0.056^{* * *} \\
(0.00)\end{array}$ & $\begin{array}{r}0.031^{*} \\
(0.06)\end{array}$ & $\begin{array}{r}0.017 \\
(0.25)\end{array}$ \\
\hline mean outcome of control households & 4.747 & 4.741 & 4.941 & 5.087 & -0.210 & -0.158 & -0.087 & -0.047 \\
\hline core set of covariates & yes & yes & yes & yes & yes & yes & yes & yes \\
\hline observations & 642 & 642 & 608 & 581 & 642 & 642 & 608 & 581 \\
\hline
\end{tabular}

Notes: Displayed is the estimated coefficient of treatment (ATE) obtained from 16 separate estimations with the core set of covariates included (see table 5 for details). P-values are reported in brackets with ${ }^{*}$ significant at $10 \%$; ${ }^{* *}$ significant at $5 \%$; ${ }^{* * *}$ significant at $1 \%$. Source: Coping with Shocks in Mongolia Household Panel Survey and Mongolia Livestock Census. 
Table 8: Robustness test: Results from double robust estimators

\begin{tabular}{|c|c|c|c|c|c|c|c|c|}
\hline \multirow[t]{2}{*}{ outcome variables } & \multicolumn{4}{|c|}{ number of livestock (in logs) } & \multicolumn{4}{|c|}{ cum. livestock growth rate } \\
\hline & $\begin{array}{r}2011 \\
(1) \\
\end{array}$ & $\begin{array}{r}2012 \\
(2) \\
\end{array}$ & $\begin{array}{r}2013 \\
(3) \\
\end{array}$ & $\begin{array}{r}2014 \\
(4) \\
\end{array}$ & $\begin{array}{c}2009- \\
2011 \\
(5) \\
\end{array}$ & $\begin{array}{c}2009- \\
2012 \\
(6)\end{array}$ & $\begin{array}{c}2009- \\
2013 \\
(7) \\
\end{array}$ & $\begin{array}{c}2009- \\
2014 \\
(8) \\
\end{array}$ \\
\hline $\begin{array}{l}\text { panel A: inverse probability-weighted } r \\
\text { purchased IBLI in } 2009\end{array}$ & $\begin{array}{c}\text { egressio } \\
0.10^{*} \\
(0.09)\end{array}$ & $\begin{array}{c}\text { adjustme } \\
0.192^{* * *} \\
(0.00)\end{array}$ & $\begin{array}{c}\text { at }(I P W \\
0.003 \\
(0.97)\end{array}$ & $\begin{array}{l}2 A) \\
0.077 \\
(0.40)\end{array}$ & $\begin{array}{l}0.009 \\
(0.69)\end{array}$ & $\begin{array}{l}0.039^{* * *} \\
(0.00)\end{array}$ & $\begin{array}{r}-0.005 \\
(0.81)\end{array}$ & $\begin{array}{l}0.009 \\
(0.60)\end{array}$ \\
\hline $\begin{array}{l}\text { panel B: augmented inverse-probability } \\
\text { purchased IBLI in } 2009\end{array}$ & $\begin{array}{l}\text { weight } \\
0.086 \\
(0.11)\end{array}$ & 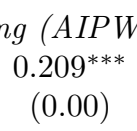 & $\begin{array}{r}-0.040 \\
(0.63)\end{array}$ & $\begin{array}{l}0.068 \\
(0.44)\end{array}$ & $\begin{array}{l}0.003 \\
(0.86)\end{array}$ & $\begin{array}{c}0.044^{* * *} \\
(0.00)\end{array}$ & $\begin{array}{r}-0.015 \\
(0.44)\end{array}$ & $\begin{array}{r}0.007 \\
(0.66)\end{array}$ \\
\hline mean outcome of control households & 4.747 & 4.741 & 4.941 & 5.087 & -0.211 & -0.158 & -0.087 & -0.047 \\
\hline core set of covariates & yes & yes & yes & yes & yes & yes & yes & yes \\
\hline observations & 642 & 642 & 608 & 581 & 642 & 642 & 608 & 581 \\
\hline
\end{tabular}

Notes: Displayed is the estimated coefficient of treatment (ATE) obtained from 16 separate estimations with the core set of covariates included (see table 5 for details). P-values are reported in brackets with ${ }^{*}$ significant at $10 \%$; ${ }^{* *}$ significant at $5 \%$; ${ }^{* * *}$ significant at 1\%. Source: Coping with Shocks in Mongolia Household Panel Survey and Mongolia Livestock Census. 
Table 9: Impact of IBLI indemnity payments on recovery from the 2009/10 dzud based on livestock in bod units (bias-corrected matching estimator)

\begin{tabular}{|c|c|c|c|c|}
\hline \multirow[t]{2}{*}{ outcome variables } & \multicolumn{4}{|c|}{ number of livestock in bod units (in logs) } \\
\hline & $\begin{array}{c}2011 \\
(1)\end{array}$ & $\begin{array}{c}2012 \\
(2)\end{array}$ & $\begin{array}{c}2013 \\
(3)\end{array}$ & $\begin{array}{c}2014 \\
(4)\end{array}$ \\
\hline purchased IBLI in 2009 & $\begin{array}{c}0.300^{* * *} \\
(0.00)\end{array}$ & $\begin{array}{c}0.385^{* * *} \\
(0.00)\end{array}$ & $\begin{array}{c}0.263^{* *} \\
(0.03)\end{array}$ & $\begin{array}{l}0.249^{*} \\
(0.06)\end{array}$ \\
\hline mean outcome of control households & 3.050 & 3.033 & 3.264 & 3.450 \\
\hline core set of covariates & yes & yes & yes & yes \\
\hline observations & 430 & 430 & 420 & 416 \\
\hline
\end{tabular}


Table 10: Robustness test: Using retrospective information on pre-shock livestock holdings and livestock losses from the third panel wave (bias-corrected matching estimator)

\begin{tabular}{|c|c|c|c|c|c|c|c|c|}
\hline \multirow[t]{2}{*}{ outcome variables } & \multicolumn{4}{|c|}{ number of livestock (in logs) } & \multicolumn{4}{|c|}{ cum. livestock growth rate } \\
\hline & $\begin{array}{l}2011 \\
(1)\end{array}$ & $\begin{array}{r}2012 \\
(2)\end{array}$ & $\begin{array}{c}2013 \\
(3)\end{array}$ & $\begin{array}{l}2014 \\
(4)\end{array}$ & $\begin{array}{c}2009- \\
2011 \\
(5)\end{array}$ & $\begin{array}{c}2009- \\
2012 \\
(6)\end{array}$ & $\begin{array}{c}2009- \\
2013 \\
(7)\end{array}$ & $\begin{array}{c}2009- \\
2014 \\
(8)\end{array}$ \\
\hline $\begin{array}{l}\text { panel A: retrospective information on } \\
\text { purchased IBLI in } 2009\end{array}$ & $\begin{array}{c}\text { livestock } \\
0.198 \\
(0.13)\end{array}$ & $\begin{array}{c}\text { ecorded in } \\
0.290^{* *} \\
(0.03)\end{array}$ & $\begin{array}{c}\text { third pan } \\
0.130 \\
(0.39)\end{array}$ & $\begin{array}{l}\text { wave } \\
0.055 \\
(0.71)\end{array}$ & $\begin{array}{l}0.055 \\
(0.18)\end{array}$ & $\begin{array}{c}0.071^{* *} \\
(0.02)\end{array}$ & $\begin{array}{l}0.026 \\
(0.34)\end{array}$ & $\begin{array}{r}0.006 \\
(0.79)\end{array}$ \\
\hline mean outcome of control households & 4.770 & 4.759 & 4.938 & 5.116 & -0.209 & -0.161 & -0.093 & -0.048 \\
\hline core set of covariates & yes & yes & yes & yes & yes & yes & yes & yes \\
\hline observations & 528 & 528 & 503 & 494 & 528 & 528 & 503 & 494 \\
\hline $\begin{array}{l}\text { panel B: retrospective information on } \\
\text { purchased IBLI in } 2009\end{array}$ & $\begin{array}{c}\text { livestock } \\
0.174^{* *} \\
(0.04)\end{array}$ & $\begin{array}{c}\text { eported by } \\
0.254^{* * *} \\
(0.00)\end{array}$ & $\begin{array}{c}\text { head of } h \\
0.176^{* *} \\
(0.04)\end{array}$ & $\begin{array}{c}\text { usehold } \\
0.143 \\
(0.16)\end{array}$ & $\begin{array}{c}\text { first or } \\
0.042 \\
(0.18)\end{array}$ & $\begin{array}{c}\text { third pane } \\
0.058^{* * *} \\
(0.00)\end{array}$ & $\begin{array}{l}\text { wave) } \\
0.035^{* *} \\
(0.04)\end{array}$ & $\begin{array}{r}0.022 \\
(0.20)\end{array}$ \\
\hline core set of control households & yes & yes & yes & yes & yes & yes & yes & yes \\
\hline mean outcome of control households & 4.776 & 4.762 & 4.937 & 5.073 & -0.197 & -0.151 & -0.084 & -0.047 \\
\hline observations & 566 & 566 & 538 & 522 & 566 & 566 & 538 & 522 \\
\hline
\end{tabular}

Notes: Displayed is the estimated coefficient of treatment (ATE) obtained from 16 separate estimations with the core set of covariates included (see table 5 for details). P-values are reported in brackets with $*$ significant at $10 \%$; ** significant at $5 \%$; *** significant at $1 \%$. Source: Coping with Shocks in Mongolia Household Panel Survey and Mongolia Livestock Census. 
Table 11: Robustness test: Impact of IBLI on livestock holdings in 2010

\begin{tabular}{|c|c|c|c|}
\hline \multirow[t]{2}{*}{ outcome variable } & \multicolumn{3}{|c|}{ number of livestock in 2010 (in logs) } \\
\hline & $\begin{array}{c}\text { bias-corrected } \\
\text { matching estimator } \\
\text { (1) }\end{array}$ & $\begin{array}{l}\text { inverse probability- } \\
\text { weighted regression } \\
\text { (IPWRA) } \\
(2)\end{array}$ & $\begin{array}{c}\text { augmented inverse- } \\
\text { probability weighting } \\
\text { (AIPW) } \\
(3)\end{array}$ \\
\hline purchased IBLI in 2009 & $\begin{array}{c}0.082 \\
(0.49)\end{array}$ & $\begin{array}{c}0.034 \\
(0.46)\end{array}$ & $\begin{array}{r}0.028 \\
(0.49)\end{array}$ \\
\hline mean outcome of control households & 4.585 & 4.585 & 4.585 \\
\hline core set of covariates & yes & yes & yes \\
\hline observations & 639 & 639 & 639 \\
\hline
\end{tabular}

Notes: Displayed is the estimated coefficient of treatment (ATE) obtained from 3 separate estimations with the core set of covariates included (see table 5 for details). P-values are reported in brackets with ${ }^{*}$ significant at $10 \%$; ** significant at $5 \%$;

*** significant at 1\%. Source: Coping with Shocks in Mongolia Household Panel Survey and Mongolia Livestock Census. 
Table 12: Impact of IBLI indemnity payments on household shock coping strategies (bias-corrected matching estimator)

\begin{tabular}{|c|c|c|c|c|c|}
\hline \multirow[t]{2}{*}{ outcome variables } & \multicolumn{5}{|c|}{ coping strategies } \\
\hline & $\begin{array}{c}\text { sold } \\
\text { livestock } \\
\text { (1) }\end{array}$ & $\begin{array}{l}\text { moved } \\
\text { livestock } \\
\text { during } \\
\text { dzud } \\
(2)\end{array}$ & $\begin{array}{l}\text { borrowed } \\
\text { money }\end{array}$ & $\begin{array}{l}\text { organized } \\
\text { additional } \\
\text { labor for } \\
\text { herding } \\
\text { (4) }\end{array}$ & $\begin{array}{l}\text { built shelter } \\
\text { or fences for } \\
\text { livestock } \\
\text { (5) }\end{array}$ \\
\hline $\begin{array}{l}\text { panel A: minimal set of covariates } \\
\text { purchased IBLI in } 2009\end{array}$ & $\begin{array}{c}-0.104^{* *} \\
(0.03)\end{array}$ & $\begin{array}{c}-0.216^{* * *} \\
(0.00)\end{array}$ & $\begin{array}{c}0.333^{* * *} \\
(0.00)\end{array}$ & $\begin{array}{l}0.008 \\
(0.90)\end{array}$ & $\begin{array}{l}-0.006 \\
(0.89)\end{array}$ \\
\hline $\begin{array}{l}\text { panel B: core set of covariates } \\
\text { purchased IBLI in } 2009\end{array}$ & $\begin{array}{l}-0.154^{* * *} \\
\quad(0.00)\end{array}$ & $\begin{array}{c}-0.094^{*} \\
(0.09)\end{array}$ & $\begin{array}{c}0.346^{* * *} \\
(0.00)\end{array}$ & $\begin{array}{l}0.103 \\
(0.17)\end{array}$ & $\begin{array}{l}0.016 \\
(0.70)\end{array}$ \\
\hline $\begin{array}{l}\text { panel } C \text { : maximal set of covariates } \\
\text { purchased IBLI in } 2009\end{array}$ & $\begin{array}{l}-0.149^{* * *} \\
(0.00)\end{array}$ & $\begin{array}{l}-0.062 \\
(0.23)\end{array}$ & $\begin{array}{c}0.249^{* * *} \\
(0.00)\end{array}$ & $\begin{array}{l}0.156^{*} \\
(0.09)\end{array}$ & $\begin{array}{l}0.030 \\
(0.58)\end{array}$ \\
\hline mean outcome of control households & 0.180 & 0.381 & 0.290 & 0.208 & 0.094 \\
\hline core set of covariates & yes & yes & yes & yes & yes \\
\hline observations & 642 & 642 & 642 & 642 & 642 \\
\hline
\end{tabular}

Notes: Displayed is the estimated coefficient of treatment (ATE) obtained from 15 separate estimations based on different sets of covariates (see table 5 for details). P-values are reported in brackets with * significant at $10 \%$; ** significant at $5 \%$; ${ }^{* * *}$ significant at $1 \%$. Source: Coping with Shocks in Mongolia Household Panel Survey and Mongolia Livestock Census. 